\title{
U źródeł japońskiego nacjonalizmu i militaryzmu — doktryna kokutai w życiu politycznym Cesarstwa Japonii w latach 1867-1945
}

\section{Wstęp}

Tematem niniejszego artykułu jest historyczny rozwój japońskiej doktryny kokutai, znanej również pod nazwą „charakteru narodowego”. Kokutai to termin, który niesie z sobą wiele treści w zależności od kontekstu, okresu w dziejach nowożytnej Japonii. Najbardziej kojarzony jest on ze źródłami japońskiego nacjonalizmu i militaryzmu, które doprowadziły do dwóch wojen w Azji Wschodniej, skutkujących śmiercią milionów ludzi oraz zniszczeniami całych krajów. Celem niniejszej pracy jest wskazanie zależności pomiędzy doktryną kokutai a japońskim nacjonalizmem i militaryzmem na przestrzeni er Meiji, Taishō oraz Shōwa do 1945 roku, które swoim zasięgiem obejmują niecały wiek historii Japonii.

Pomimo żywego zainteresowania prawników i historyków tematyką podstaw ideologicznych włoskiego faszyzmu i niemieckiego nazizmu źródła japońskiego nacjonalizmu, do których niewątpliwie należy doktryna kokutai, nie cieszą się w Polsce dużą popularnością. Prekursorką badań nad związkami pomiędzy „charakterem narodowym” a japońskim militaryzmem jest Ewa Pałasz-Rutkowska, historyk i japonista, która w latach 90. opublikowała dwie prace poświęcone temu zagadnieniu1. Dużo szersza analiza historycznego procesu rozwoju kokutai, jak również omówienie kluczowego dokumentu Kokutai no hongi zawarte są

${ }^{1}$ E. Pałasz-Rutkowska, General Masaki Jinzaburō and the Imperial Way Faction (Kōdōha) in the Japanese Army, 1932-1936, Warszawa 1990; eadem, Działania armii japońskiej na rzecz obrony kokutai, narodowego charakteru, pod wphywami obcymi (lata trzydzieste XX w.), „Japonica” 1993, nr 1. 
w wydanej w 2010 roku pracy filozofa i politologa Marcina Lisieckiego ${ }^{2}$. Poza tymi dwoma monografiami i jednym artykułem brak w Polsce innych opracowań tego tematu. Większą popularnością cieszą się dzieła poświęcone kulturze, religii oraz sztuce japońskiej.

Przed potencjalnym badaczem historii, prawa oraz doktryn politycznych Japonii stoi wiele utrudnień. Należy do nich przede wszystkim szeroki zasób źródeł i literatury przedmiotu w języku japońskim. Prace te są napisane we współczesnym języku japońskim oraz w języku sprzed wielkiej powojennej reformy ortograficznej. Do innych utrudnień należy również zaliczyć znaczne rozczłonkowanie źródeł pierwotnych oraz mnogość opracowań w różnych językach świata - angielskim, niemieckim, francuskim, rosyjskim czy nawet hiszpańskim. Niniejszy artykuł w znacznej części jest oparty na źródłach i opracowaniach japońsko- i anglojęzycznych, przy wsparciu materiałów francusko- i niemieckojęzycznych, które autor uważał za najważniejsze dla zwięzłego ujęcia złożoności omawianej problematyki.

Przy pisowni japońskich nazw własnych i terminów autor skorzystał z Hebon-shiki rōmaji, czyli transkrypcji Hepburna, która pozwala na zapis znaków kanji, hiragany i katakany $\mathrm{w}$ alfabecie łacińskim ze specyficznymi znakami diakrytycznymi charakteryzującymi japońską wymowę. Japońskie personalia pojawiające się $\mathrm{w}$ tekście zostały przedstawione $\mathrm{w}$ porządku: imię, a następnie nazwisko. Jest to świadome złamanie zasad przyjętych w językach wschodnioazjatyckich, które ułatwi polskiemu czytelnikowi odbiór niniejszego artykułu.

\section{Pochodzenie i znaczenie terminu kokutai}

Źródeł terminu kokutai należy szukać w języku i kulturze chińskiej, które przez wieki promieniowały na leżącą na wschód od Państwa Środka Japonię. Już w datowanym na II wiek p.n.e. Gǔliáng Zhuàn (pol. Komentarz Guliang), odnoszącym się do starożytnej Chūnqiū (pol. Kronika Wiosen i Jesieni), pojawiło się określenie naczelnego ministra, dafu, którego w sposób metaforyczny nazywano „guótî” (tradycyjny chiński: 國體, chiński uproszczony: 国体), czyli „ucieleśnieniem narodu, kraju”3. Drugie chronologicznie chińskie źródło wspominające o „guót’’” to Hànsh ū (pol. Księga Hanów) — tradycyjne dzieło przedstawiające dzieje wczesnej dynastii Han. W rozdziale poświęconym cesarzowi Chengi ,guótī” przedstawiono jako prawa i zarządzenia wydawane przez organy konfucjańskiej władzy ${ }^{4}$.

${ }^{2}$ M. Lisiecki, Kokutai-no hongi w japońskim dyskursie nacjonalistycznym, Torun 2010.

3 穀梁傳 (Güliáng Zhuàn - pol. Komentarze Gulianga).

4 汉书: 卷10成帝紀 (Hànshū: Juăn 10 Chéngdì Ji - pol. Księga Hanów, t. 10, Roczniki Cesarza Chengi). 
Przez kolejne wieki termin „guótı̄” pojawiał się w pracach chińskich historyków i myślicieli, nie miał jednak on żadnego zabarwienia ideologicznego. Dopiero w XIX wieku na trwałe na japoński grunt przeniósł go Seishisai Aizawa - przedstawiciel doktryny neokonfucjańskiej i zwierzchnik Szkoły Mito wspierającej restaurację władzy cesarskiej w okresie szogunatu. W swojej pracy zatytułowanej Shinron (pol. Nowe Tezy) wydanej w 1825 roku użył po raz pierwszy i spopularyzował słowo kokutai, które bezpośrednio odnosiło się do chińskiego „guótî”. Różnice w brzmieniu tego terminu w języku japońskim i chińskim wynikały z odmiennego sposobu czytania znaków kanji w obu krajach. Powstały wskutek połączenia dwóch słów termin kokutai („koku” — kraj, państwo i „tai” — ciało, forma) może być przekładany na języki europejskie w różny sposób ${ }^{6}$. Przykładowo, w języku angielskim badacze najczęściej posługują się formami: „ustrój narodowy” (ang. national polity), „wspólnota narodowa” (ang. national community) i ,istota narodowa” (ang. national essence) ${ }^{7}$. Ostatnia z form wykorzystywana jest również przez niemieckich badaczy (niem. Nationalwesens) na równi z „cechą narodową” (niem. Nationale Eigenschaft) ${ }^{8}$. W języku francuskim dominują przekłady utożsamiające kokutai z ,istotą narodową” (fr. l'essence nationale) i „wspólnotą narodową" (fr. l'unité nationale) ${ }^{9}$, podczas gdy polscy japoniści, idąc za wzorem prof. Ewy Pałasz-Rutkowskiej, najczęściej korzystają $\mathrm{z}$ terminu ,charakter narodowy" 10 . W praktyce polski badacz może również powoływać się na przekłady dosłowne, takie jak np. „ciało narodu”, „ucieleśnienie narodu”, „esencja narodu” lub po prostu „kształt państwa”, ponieważ nie istnieje jedyne prawidłowe tłumaczenie terminu kokutai. W celu zachowania spójności $\mathrm{z}$ dorobkiem polskich japonistów w niniejszej pracy będę przeważnie posługiwał się formami „,charakter narodowy” i ,istota narodowa”, ponieważ odnoszą się one bezpośrednio do idei lansowanych przez japońskich przedstawicieli doktryny nacjonalistycznej.

5 S. Aizawa, 新論 (Shinron - pol. Nowe Tezy), http://www.1-em.net/sampo/sinron/sinron/ index.htm (dostęp: 21.07.2016).

6 M. Lisiecki, op. cit., s. 12-13.

7 J.M. Kitagawa, The Japanese kokutai (National Community) History and Myth, „History of Religions" 1976, vol. 13, no 3, s. 209-226; W.M. Fridell, National Essence; National Polity (Kokutai), [w:] Modern Japan: An Encyclopedia of History, Culture and Nationalism, red. J.L. Huffman, New York-London 1998, s. 169; Kokutai, [hasło w:] Kodansha Encyclopedia of Japan, t. 4, Tōkyō 1983, s. 262.

${ }^{8}$ K. Antoni, Shintō und die Konzeption des Japanischen Nationalwesens (Kokutai): der religiöse Traditionalismus in Neuzeit und Moderne Japans, Boston 1998.

${ }^{9}$ F. Macé, Deux interprétations croisées du shintō, le père Martin et Katō Genchi, [w:] France-Japon: regards croisés, red. C. Mayaux, Bern 2007; P. Lavelle, L'essence nationale du Japon, [w:] Y.M. Allioux, Cent ans de pensée au Japon, t. 2, Arles 1998.

10 E. Pałasz-Rutkowska, Działania..., s. 37-46. 


\section{Kokutai a Japonia Ery Edo}

Tezy Aizawy dotyczące kokutai stanowiły rozwinięcie wykładów Norinagi Motooriego z lat 1771-1794, który nauczał, iż japońskie mity założycielskie zwarte w starożytnych kronikach Kojiki i Nihon Shoki były historycznymi faktami, cesarz zaś faktycznie pochodził bezpośrednio od bogini słońca, głównego bóstwa religii shintō - Amaterasu ${ }^{11}$. Boskie pochodzenie cesarza, a także fakt istnienia jednej nieprzerwanej dynastii od czasów mitycznego założenia kraju miały legitymizować jedność władzy nad życiem ziemskim i duchowym Japończyków ${ }^{12}$. Pomimo tego, że Motoori nie stworzył samodzielnie żadnej ideologii i jego zamiarem było oczyszczenie shintō z buddyjskich i konfucjańskich interpretacji, przedstawione przez niego założenia o wyjątkowości Japonii i Japończyków stały się podstawą do sformułowania przez Aizawę nowej myśli politycznej ${ }^{13}$.

W czasach kryzysu władzy centralnej w Japonii w trzeciej dekadzie XIX wieku i stopniowej penetracji Azji Wschodniej przez mocarstwa zachodnie Aizawa rozumiał, że Japończycy muszą przeciwstawić groźbie kolonizacji i utraty suwerenności duchową jedność narodową. Według Japończyka samurajowie wojownicy chroniący Japonię - przenosząc się do miast i zajmując się głównie handlem, stali się wygodni i słabi. Żądza bogacenia się zmieniła mentalność rządu i elit kraju, które coraz bardziej podążały ścieżką chińskiego skorumpowanego buddyzmu ${ }^{14}$. Aizawa jednocześnie ostrzegał, iż kolonizatorzy z Zachodu dysponowali wielką siłą. Jej źródeł doszukiwał się w chrześcijaństwie, które jego zdaniem motywowało Europejczyków do dalszych podbojów pomimo istnienia wyraźnych różnic narodowych. Podobną siłę Aizawa widział w narodzie japońskim po raz ostatni w odległych czasach, w starożytności, kiedy to przybrała ona formę saisei ichi — jedności rządów administracyjnych oraz religii shintō. Jedność ta miała zostać ustanowiona przez Amaterasu i przekazana jej potomkom, którymi byli kolejni cesarze ${ }^{15}$. W celu zachowania harmonii bogini stworzyła ponadto trzy insygnia zwane Trzema Boskimi Skarbami (jap. Sanshu no Jingi) — metalowe lustro z ośmioma uchwytami (jap. Yata no Kagami), pięćset klejnotów (jap.

11 Zob. H.G. Blocker, C.L. Starling, Filozofia japońska, Kraków 2008.

12 N. Motoori, 直毘霊 (Naobi no Mitama - pol. Ścieżka Bogów), przedruk pracy wydany w Tokio w 1914 roku.

13 J.S. Brownlee, Four Stages of the Japanese Kokutai (National Essence), zapis przemówienia z konferencji JSAC na Uniwersytecie Brytyjskiej Kolumbii, październik 2000 roku.

14 J.L. McClain, Japan: A Modern History, New York 2002, s. 132; por. S. Aizawa, op. cit.

15 Istotną różnicą pomiędzy chrześcijańskimi monarchami a japońskimi cesarzami była legitymizacja ich władzy. W Europie podkreślano, iż władca obejmuje tron ,z Bożej Łaski” (łac. Dei Gratia), podczas gdy w Japonii cesarz był bezpośrednio traktowany jako bóstwo (jap. 神, kami). J.V. López, Beyond words: the kokutai and its background, „Història Moderna i Contemporània” 2006, nr 4, s. 127. 
Yusaka no Matagama) i święty Miecz Trawosiecz (Kusanaga no Tsurugu) ${ }^{16}$, które wykorzystywane przez cesarzy z najwyższą czcią i z zachowaniem wszelkich cnót miały pomóc w utrzymaniu jedności narodowej.

W swoich tezach Aizawa odnosił się także do rzeczywistej sytuacji politycznej panującej w Japonii, tj. dominacji szogunów z rodu Tokugawa. Jedność i nadzwyczajna siła Japończyków miały tkwić w odnowie duchowej i religijnej, co Aizawa thumaczył poprzez tradycyjne mity. Zdaniem Japończyka Amaterasu szczególnie miała cenić sobie lojalność i szczere oddanie ${ }^{17}$. Według Boba Wakabayashiego sformułowany przez Aizawę w Nowych Tezach termin kokutai oznaczał „duchową jedność narodową” - dobrowolne przywiązanie i zaufanie pobratymców w stosunku do ich przywódców [czyli cesarzy — przyp. M.A.P.]"18. Jedność ta miała zostać osiągnięta poprzez realizację radykalnego programu politycznego, który swoim zakresem obejmował: powrót samurajów z miast do majątków ziemskich, reformę administracji centralnej, wzmocnienie obrony wybrzeża przed wrogimi statkami, wygnanie wszystkich cudzoziemców z Japonii, całkowite porzucenie zachodnich zwyczajów oraz, co najważniejsze, przywrócenie przez szoguna szczególnej roli cesarza jako tradycyjnego władcy religijnego Japonii ${ }^{19}$.

Ogólnie jednak w japońskiej filozofii neokonfucjańskiej z pierwszej połowy XIX wieku ,jedność narodowa” swoim zakresem obejmowała odnowę płaszczyzny duchowej bez odwoływania się do polityki władz lub obowiązującego prawa.

\section{Kokutai w dobie restauracji władzy cesarskiej}

Modernizacja Cesarstwa Japonii w początkowym okresie ery Meiji przyniosła z sobą powrót do doktryny kokutai. Jej ponowną interpretacją zajęli się dwaj najważniejsi przedstawiciele japońskiej myśli liberalnej — Hiroyuki Katō i Yukichi Fukuzawa. Jako podstawę swoich rozważań Japończycy przyjęli pogląd, według którego najbardziej zaawansowanymi narodami pod względem cywilizacyjnym są tzw. kraje zachodnie. Ich sukces wynikał z promowania określonego ustroju, systemu wartości i instytucji prawa. W wydawanym przez pewien czas czasopiśmie Meiroku Zasshi (pol. Czasopismo Towarzystwa Meiji Sześć) przekonywano o potędze państw zachodnich i tłumaczono w sposób racjonalny ich wyższość, krytykując jednocześnie zacofanie japońskiego społeczeństwa, które

16 J.O. Gauntlett, R.K. Hall, Kokutai no Hongi: Cardinal Principles of the National Entity of Japan, Cambridge 1949, s. 20.

17 S. Aizawa, op. cit.

18 B.T. Wakabayashi, Anti-Foreignism and Western Learning in Early Modern Japan: The New Theses of 1825, Harvard 1992, s. 123-124.

19 J.L. McClain, op. cit., s. 132. 
mentalnie miało znajdować się w odległej epoce. Zdaniem japońskich liberałów jedyne rozwiązanie tego problemu miało polegać na bezprecendesowej i błyskawicznej modernizacji własnego kraju poprzez bezkrytyczne przyjęcie zachodnich wzorców ${ }^{20}$.

Pogląd ten znacząco zrywał z dotychczasowym wyobrażeniem Japończyków o wyjątkowości ich kraju. Wyjątkowość ta w przeszłości była podkreślana między innymi przez jednego z najbardziej uznanych nadwornych filozofów rodu Tokugawa, Sokō Yamanagę, który pisał w Chūchō Jijitsu: „Kraj zwany Japonią wznosi się wysoko ponad inne państwa, a jego ludzie górują nad innymi narodami na świecie"21. Co prawda w drugiej połowie XIX wieku japońskie władze w dalszym ciągu były przekonane o wyjątkowości Japonii w skali świata, przedkładały one jednak postulat modernizacji państwa ponad poczucie narodowej dumy. O tym, że zachodnie systemy prawa zostały ostatecznie uznane za doskonalsze od japońskiego prawa zwyczajowego, świadczy przebieg prac nad nową konstytucją oraz pierwsze próby kodyfikacji gałęzi prawa cywilnego i karnego ${ }^{22}$.

W wydanej w 1868 roku pracy Rikken Seitai Ryaku (pol. Zarys Władzy Konstytycyjnej) Katō jednoznaczenie odrzucał konfucjański i neokonfucjański model sprawowania władzy przez cesarza. Pomimo tego, iż Japończyk nie był przeciwny idei monarchii, w swoich rozważaniach negował tradycyjną boską legitymizację głowy państwa w Japonii. Analizując przykłady monarchii organiczonych i konstytucyjnych, a także republik, dowodził on, że nie wolno utożsamiać osoby panującego lub demokratycznie wybranego rządu z całym państwem i narodem. Katō mocno krytykował modele absolutystyczne, w tym popieraną przez skrajnych nacjonalistów, także konserwatystów, absolutną władzę cesarza Japonii. Jego zdaniem rozwój społeczny ludzkości w drugiej połowie XIX wieku posunął się do takiego stopnia, iż obywatele dobrowolnie udzielili cesarzowi lub rządowi mandatu do sprawowania władzy. Istnienie kontraktu społecznego miało gwarantować stabilność rządów oraz respektowanie praw obywateli ${ }^{23}$.

${ }^{20}$ Meiroku Zasshi poruszało wiele tematów związanych z prawem, polityką, historią, ekonomią, socjologią, prawami kobiet i językiem. Szczególnym zainteresowaniem wśród japońskich autorów cieszyły się Stany Zjednoczone, Wielka Brytania, Francja, Niemcy i Szwajcaria. Na łamach pisma na bieżąco relacjonowano prace nad nowymi kodyfikacjami w Europie oraz tłumaczono, czym jest liberalizm, któremu poświęcano najwięcej miejsca spośród wszystkich doktryn. Choć czasopismo funkcjonowało zaledwie dwa lata, zdołano wydać łącznie aż 43 numery. 明六雑誌 (Meiroku Zasshi), Dai 1-43 Go, Tōkyō 1874-1875. Zob. W.R. Braisted, Meiroku Zasshi: Journal of the Japanese Enlightenment, Harvard 1976; P. Varley, Japanese Culture, Honolulu 2000, s. 242.

21 Zob. S. Yamanaga, 中朝事実 (Chūchō Jijitsu - pol. Obecne fakty o władzy centralnej), Tōkyō 2015.

22 Zob. M.A. Piegzik, Rozwój szkót prawa w Japonii w okresie ery Meiji, „Folia Iuridica Univeristatis Wratislaviensis" 2016, t. 5, nr 1.

${ }^{23}$ H. Katō, 立憲政體略 (Rikken Seitai Ryaku - pol. Zarys Władzy Konstytycyjnej), Tōkyō 1868, s. 10-14. 
Po sformułowaniu podstawowych założeń doktrynalnych Katō przystąpił do otwartej krytyki azjatyckich koncepcji zarządzania państwem, skupiając się na rodzimych ideach narodowych przybierających formę naukowych tez. Jego argumenty zostały przedstawione w pracy zatytułowanej Kokutai Shinron (pol. Nowa Teoria Kokutai), wydanej w 1874 roku. Za podstawowy błąd Japończyk uważał akceptowanie funkcjonującego przez ponad dwa tysiące lat twierdzenia, iż ziema oraz ludzie ją zamieszkujący należą do władcy kraju, który w założeniach zawsze reprezentuje najwyższą cnotę i dobro. Będąc pod silnym wpływem poglądów holenderskich, niemieckich, a w szczególności angielskich naturalistów, Katō utożsamiał państwo idealne z takim, które ograniczałoby swoją rolę jedynie do ochrony życia, wolności i prawa własności ${ }^{24}$. Jednym z najważniejszych punktów Nowej Teorii Kokutai było również przekonanie, że obywatele mają prawo przeciwstawić się rządowi, gdy ten nie będzie wywiązywał się ze swoich podstawowych obowiązków. Za przykład uzasadnionego nieposłuszeństwa Japończyk wskazał amerykańską rewolucję wymierzoną przeciwko koronie brytyjskiej, która doprowadziła do utworzenia Stanów Zjednoczonych ${ }^{25}$.

Kluczowe dla zagadnienia kokutai objaśnienia zawierał rozdział siódmy dzieła Katō. Japończyk wyraźnie odróżniał kokutai, ucieleśnienie narodu, od seitai, czyli formy rządów. Nie wiadomo, czy był on pierwszą osobą, która stworzyla ten podział, lecz, jak podkreśla J. Brownlee, oba terminy stały się kluczowym elementem politycznych i konstytucyjnych debat w Japonii aż do 1945 roku — ostatecznej klęski w wojnie ze Stanami Zjednoczonymi i końcem epoki militaryzmu ${ }^{26}$.

Kokutai, nazywane „narodową esencją”, czy też „natywnym japońskim pierwiastkiem", było według Katō wieczną, niezmienną cechą Japonii, wywodzącą się bezpośrednio z jej historii, tradycji i zwyczajów. Jej ucieleśnieniem była osoba cesarza. Uzupełnienie dla kokutai stanowiło seitai, a więc forma rząów, która została ustanowiona u progu istnienia narodu japońskiego i w toku dziejów ulegała pewnym modyfikacjom. Pierwsi cesarze, założyciele Japonii, mieli boską legitymizację. Ich sukcesorami w okresie średniowiecza stali sie regenci

24 Jeszcze w czasach rządów rodu Tokugawa Katō był instruktorem-specjalistą w Bansho Shirabesho (pol. Instytut Badań nad Książkami Barbarzyńskimi) jako osoba biegła w naukach holenderskich (jap. rangaku), szerzej — naukach państw zachodnich. W 1860 roku jako pierwszy Japończyk otrzymał od szogunatu szansę studiowania języka niemieckiego i niemieckiej filozofii. Jego fascynacja prądami intelektualnymi pochodzącymi z Wielkiej Brytanii i Niemiec spowodowana była chęcią uczynienia z Japonii potęgi gospodarczej i politycznej. Po przywróceniu władzy cesarskiej dołączył do liberalnej partii Rikken Seiyūkai (pol. Konstytucyjne Stowarzyszenie Przyjaciół Polityki). Za swoje zasługi w modernizacji Japonii został w 1881 roku mianowany Dziekanem Wydziału Prawa Uniwersytetu Tokijskiego. Zob. M. Hachirō, 加藤弘之の前期政治 思想 (Katō Hiroyuki no Zenki Seiji Shisō — pol. Niegdysiejsze Doktryny Polityczne Hiroyukiego Katō), Tōkyō 1983; L.F. Nussbaum, Japan Encyclopedia, London 2005, s. 491.

25 K. Katō, 国体新論 (Kokutai Shinron - pol. Nowa Teoria Kokutai), Tōkyō 1874, s. 21-24, http://dl.ndl.go.jp/info:ndljp/pid/759337 (dostęp: 30.07.2016).

26 J.S. Brownlee, op. cit. 
z rodu Fujiwara, których to z kolei zastąpili w XVII wieku szoguni z rodu Tokugawa. Restauracja władzy cesarskiej za rządów Mutsuhito sprawiła, iż historia zatoczyła swoje koło, Japonia zaś wróciła do pierwotnej formy rządów. Istotnym elementem teorii seitai było zachowanie ciągłości państwa na przestrzeni wieków, a zatem nieprzerwane istnienie narodu japońskiego ${ }^{27}$.

Pierwsze lata w pełni udanych reform w zacofanej społecznie Japonii zadziwiły Katō, który porzucił idee liberalne na rzecz darwinizmu społecznego. Pomimo tego, że Japończyk w dalszym ciągu dostrzegał analogie pomiędzy demokratycznie wybranym rządem i naturalnym porządkiem, po konferencji w Osace w 1875 roku $^{28}$ dołączył do Rady Starszych (jap. Genrōin) i poparł wprowadzenie silnej władzy wspieranej przez grupę zaufanych doradców. Autorytarny etatyzm Katō znacząco różnił od jego pierwszych postulatów i całkowicie rozmijał się z wizją liberalnej partii Ruchu na Rzecz Wolności i Praw Obywateli (jap. Jiyu Minken Undō). Odchodząc całkowicie od popierania koncepcji prawa naturalnego, Japończyk doszedł do wniosku, że prawa człowieka nie wynikają z przesłanek onotologicznych, a więc samego faktu istnienia, lecz muszą zostać wprowadzone i zagwarantowane siłą. Jeżeli naród lub człowiek charakteryzuje się słabością wobec innych narodów lub ludzi, naturalnym zjawiskiem jest utrata praw podstawowych i degradacja społeczna. Pomimo tego, że Katō osobiście udzielał cesarzowi Meiji wykładów na temat prawa konstytucyjnego, w tym trójpodziału władz, prawa międzynarodowego oraz historii ustrojów i administracji w Europie, w ostatnich latach swojego życia zanegował przezentowaną niegdyś myśl liberalno-demokratyczną, stając się zwolennikiem niepodzielnej władzy cesarskiej. Jak później wspominał, jego doktryna kokutai powróciła do tradycyjnego rozumienia tego terminu jako ,jedności narodowej”, ponieważ zmienił swój światopogląd pod wpływem lektury nowych opracowań oraz doświadczeń życiowych ${ }^{29}$.

Uzupełnienie liberalnych poglądów Katō na kwestię kokutai w epoce Meiji stanowiła praca Yukichiego Fukuzawy zatytułowana Bum'meiron no Gairyaku (pol. Zarys Teorii Cywilizacji). Fukuzawa przekonywał w niej, że kokutai, czyli „,narodowa esencja”, nie jest zarezerwowana jedynie dla Japonii, lecz również posiadają ją inne kraje, w tym lekceważone przez Japończyków w tym czasie Chiny. Najważniejszym elementem nowej interpretacji doktryny kokutai był jednak pogląd, według którego „narodowa esencja” nie była rzeczą stałą i niezmienną,

27 H. Katō, op. cit., s. 29-32.

28 Konferencja w Osace (jap. Ōsaka Kaigi) była cyklem spotkań najbardziej wpływowych postaci początkowego okresu ery Meiji, które miały miejsce w styczniu i lutym 1875 roku w celu ustalenia kierunku polityki wewnętrznej oraz zagranicznej reformowanego państwa. W tym czasie w Japonii nie funkcjonował jeszcze parlament (który powołano dopiero w 1889 roku na mocy Konstytucji Meiji), dlatego też wszystkie podjęte decyzje zostały usankcjonowane przez cesarza w kwietniu tego samego roku. Wśród postanowień japońskich decydentów znajdował się również postulat wprowadzenia Prawa Zachowującego Pokój, mającego na celu ograniczanie rozstającego się ruchu liberalnego.

29 J.S. Brownlee, op. cit. 
ponieważ ulegała ciągłej ewolucji. Jak wskazuje autor Zarysu Teorii Cywilizacji, „istota narodowa” mogła zostać wzmocniona wskutek zjednoczenia, a osłabiona poprzez podział; mogła rozszerzać się lub cofać terytorialnie. W ostateczności mogła także całkowicie zniknąć, lecz nie z powodów językowych czy religijnych. Najważniejszym aspektem ,istoty narodowej” dla Fukuzawy była suwerenność rozumiana przede wszystkim jako niezależność od podmiotów zewnętrznych. Japonia zachowała swoją tożsamość pomimo wieków walk wewnętrznych, głównie dzięki wykorzystanej szansy na modernizację ${ }^{30}$. W przeciwieństwie do swoich poprzedników Japończyk nie utożsamiał ,istoty narodowej” z osobą cesarza, ponieważ w centrum umieszczał suwerenność narodu. Pomimo krytyki nieustannego podkreślania boskiego pochodzenia cesarza $\mathrm{w}$ dyskursie publicznym, w pracy Sonnō Ron (pol. Dyskusja nad Wiernością Wobec Cesarza) wydanej w 1887 roku Fukuzawa wyraźnie podkreślał, że ,panujący dom cesarskiej Japonii jest majestatyczny i najświętszy"31. W opisie rodziny cesarskiej zawarł on ponadto takie określenia, jak „majestat”, „świętość”, „nieprzerwane pochodzenie po wsze czasy", które stały się popularne w kręgach nacjonalistycznych ${ }^{32}$. Zdaniem Japończyka powołującego się na historyczne przykłady potężnych Wielkiej Brytanii i Francji monarcha był istotnym elementem narodu jako głowa państwa dzierżąca władzę ponad wszystkimi wewnętrznymi podziałami politycznymi. Republikańskie Stany Zjednoczone miały stanowić wyjątek, lecz Fukuzawa nie popierał w tym przypadku połączenia roli głowy państwa z szefem rządu ${ }^{33}$.

\section{Kokutai jako oficjalna doktryna państwowa}

Dotychczasowe spory teoretyczne nad znaczeniem terminu kokutai i jego rolą w polityce Japonii zostały przerwane przez promulgowanie w dniu 11 lutego 1889 roku Konstytucji Japonii (jap. Dai Nippon Teikoku Kempō), zwanej powszechnie Konstytucją Meiji (jap. Meiji Kempō). Celem pierwszej w historii Japonii ustawy zasadniczej, oprócz uporządkowania kwestii wewnętrznych w państwie, była edukacja japońskiego społeczeństwa w duchu wierności wobec władzy oraz wskazania najważniejszych obowiązków obywateli, których traktowano jako poddanych. Podążając za przykładem państw zachodnich, Japończycy zamierzali przyjąć system konstytucyjny, lecz miał on podkreślać wyjątkowość cesarza jako naczelnego kapłana shintō. Już w art. 1 konstytucji stanowiono, że w Cesarstwie Japonii po wsze czasy będzie panować i rządzić nieprzerwana linia cesarzy. Po art.

${ }^{30}$ Y. Fukuzawa, 文明論之概略 (Bum'meiron no Gairyaku — pol. Zarys Teorii Cywilizacji), Tōkyō 1875, http://www.geocities.jp/hgonzaemon/bunmeironnogairyaku.html (dostęp: 12.06.2016).

31 Y. Fukuzawa, 尊皇論 (Sonnō Ron — pol. Dyskusja nad Wiernością Wobec Cesarza), [w:] Y. Fukuzawa, Nihon Teishitsu Ron, Tōkyō 1887, s. 25-100.

32 J.S. Brownlee, op. cit.

33 Ibidem. 
2, który wskazywał kolejność dziedziczenia tronu, w art. 3 potwierdzano sakralny charakter osoby cesarza i jego całkowitą nietykalność. Artykuł 4 konkretyzował normy zawarte w art. 1, potwierdzając, iż na czele Cesarstwa stoi Cesarz, który jest utożsamiany z suwerennością państwa, jak również ma prawo do jej realizacji pod warunkiem przestrzegania postanowień konstytucji ${ }^{34}$.

Na podstawie przytoczonych przepisów Konstytucji Meiji można wyciągnąć wniosek, że akt prawny najwyższej rangi, jakim niewątpliwie jest ustawa zasadnicza, ustanawiał porządek świecko-sakralny, w którym cesarz był bogiem ograniczonym jedynie nielicznymi normami. Pomimo aspiracji do reformy państwa w duchu zachodnim twórcy Konstytucji Japonii zdecydowali się poprzeć dawne postulaty przedstawicieli szkoły Mito i podnieść kokutai do rangi oficjalnej doktryny państwowej. Cesarz, który od tej pory był utożsamiany z suwerennością całej Japonii i narodu japońskiego, stał się żywym uosobieniem kokutai ${ }^{35}$.

Podkreślanie nieprzerwanego pochodzenia cesarza, którego linia dynastyczna sięgała czasów mitycznego stworzenia Japonii przez bogów, miało na celu stworzenie wyidealizowanego obrazu historii własnego państwa. Istotnym elementem ówczesnego porządku prawnego była przeszłość, na której miała zostać oparta XIX i XX-wieczna japońska tożsamość narodowa. Odwoływanie się do korzeni jako elementu łączącego cały naród Japonii w jedno ciało po wielu wiekach „nieświadomości” nie było niczym nowym. Podobne przesłanki cechowały również niemiecki i rosyjski nacjonalizm. Wyrastały one z poczucia, iż brak zakorzenienia oznacza „brak sił życiowych, a tym samym i właściwie brak funkcjonującej duszy”. Brak korzeni miał być „,wyrokiem na człowieka, podczas gdy ich posiadanie przywracało człowieczeństwo, bo równało się przynależności do Vol$k u^{\prime 36}$. Z dzisiejszej perspektywy można uznać, że same instytucje prawa, także te mające za zadanie centralizację kraju, były zdaniem reformatorów ery Meiji niewystarczające do ochrony narodu. Elementem konsolidacji wszystkich Japończyków miała być idea kokutai, która miała polegać na wspieraniu polityki, zarówno na poziomie instytucjonalnym, jak i w sferze doraźnych działań, w czym można upatrywać połączenia ideologii z pragmatyką ${ }^{37}$. Istotną cechą doktryny kokutai dla elit rządzących Japonią było również nieustanne odwoływanie się przez nią do mitycznej historii kraju, zapisanej w dwóch kronikach - Kojiki i Nihonshoki, co miało utwierdzać naród japoński w przekonaniu, iż ówczesny porządek miał boską legitymizację i był wieczny.

Zaledwie rok po promulgacji Konstytucji Japonii, w dniu 30 października 1890 roku, wydany został Cesarski Reskrypt o Wychowaniu (jap. Kyōiku ni

34 大日本帝国憲法 (Dai Nippon Teikoku Kempō — pol. Konstytucja Cesarstwa Japonii), http://www.ndl.go.jp/constitution/etc/j02.html (dostęp: 12.07.2016).

35 A. Kość, Filozoficzne podstawy prawa japońskiego w perspektywie historycznej, Lublin 2001, s. 85-86; P. Varley, op. cit., s. 255.

36 G.L. Mosse, Kryzys ideologii niemieckiej, Warszawa 1972, cyt. za: M. Lisiecki, op. cit., s. 20.

37 M. Lisiecki, op. cit., s. 12. 
kansuru Chokugo), który choć bezpośrednio nie wspominał o kokutai, jednoznacznie odnosił się do doktryny ,jedności narodowej”. O szczególnym znaczeniu tego aktu prawnego świadczy fakt, że został on przeczytany publicznie we wszystkich szkołach w Japonii, uczniowie i studenci zaś otrzymali polecenie jego dogłębnego studiowania, a nawet nauki na pamięć ${ }^{38}$. Krótki, gdyż liczący zaledwie 315 znaków tekst, miał na celu przekazanie społeczeństwu konieczności modernizacji kraju i wspierania władz w obliczu nadchodzących zmian. Już we wstępie reskryptu położono nacisk na wykazanie boskiego pochodzenia cesarza i ciągłości dynastycznej. Naród ze swojej strony miał zachować życzliwość w stosunkach międzyludzkich (rodzinnych i oficjalnych), skromność, chęć rozwoju intelektualnego i kultywowania sztuki, moralną siłę, jak również przedkładać dobro ogółu ponad własne. Przede wszystkim jednak Japończycy mieli przestrzegać nowej konstytucji oraz popierać dwór cesarski w sprawach z zakresu polityki zagranicznej i wewnętrznej ${ }^{39}$.

W latach 80. i 90. XIX wieku w Japonii doszło do niespodziewanego zwrotu w kwestii postrzegania procesu westernizacji kraju. O ile elity rządzące w dalszym ciągu popierały przyspieszoną industrializację, kodyfikację prawa we wszystkich jego gałęziach i sprowadzanie z Europy wojskowych doradców, o tyle zachodnie wzorce kulturowe zostały uznane za zagrażające jedności narodowej Japończyków. Japońskie społeczeństwo, tradycyjnie konserwatywne, miało nie być przygotowane do takich doktryn, jak chrześcijańska demokracja, liberalizm czy też socjalizm. Ich przeniesienie na japoński grunt, szczególnie wśród mas, było postrzegane jako potencjalny element obcych wpływów i ingerencji w suwerenność. W miejsce indywidualizmu i wolnej wymiany myśli rząd planował umocnienie poczucia obowiązku wobec kraju i lojalności wobec cesarza. Formułą polityczną gwarantującą wierność Japończyków i stabilizację polityczną miało być kokutai, które znacząco poszerzyło swój zakres znaczeniowy od czasów Motooriego i Aizawy ${ }^{40}$. Naczelnym mottem japońskich elit w tamtym czasie stały się głoszone dwie dekady wcześniej poglądy Shōzana Sakumy, uczonego i polityka ery Meiji, który postulował przeprowadzenie reform zgodnie z hasłem ,wschodnia etyka, zachodnia technologia” (jap. tōyō dōtoku, seiyō gakugei $)^{41}$. W krótkim czasie dewiza ta przybrała zmodyfikowaną,

38 1890年(明治23年) 10月31日付官報 (1890-nen, Meiji 23-nen, 10-gatsu, 31-nichigetsu Kampō — pl. „Gazeta Kampō” z 31 października 1890 roku), http://dl.ndl.go.jp/info:ndljp/ pid/2945456/3 (dostęp: 25.09.2016).

39 教育二関スル勅語 (Kyōiku ni kansuru Chokugo — pl. Cesarski Reskrypt o Edukacji), http://www.archives.go.jp/ayumi/kobetsu/m23_1890_02.html (dostęp: 16.09.2016); K. Yatsuki, 天 皇と日本の近代 下「教育勅語」の思想 (Ten'nō to Nihon no kindai shi „,Kyōiku Chokugo” no shisō - pol. Cesarz i wspótczesna Japonia - ideologia Rekrytpu o Edukacji), Tōkyō 2001.

40 P. Varley, op. cit., s. 248.

41 Y. Sakamoto, 佐久間象山の洋学研究とその教育的発展一幕末期における軍事科学 を媒介とした洋学の普及現象 (Sakuma Shōzan no yōgaku kenkyū to sono kyōikuteki hattenbakumatsuki ni okeru gunji kagaku o baikai to shita yōgaku no fukyū genshō — pol. Sakuma Shōzan $i$ jego badania nad naukami zachodnimi i ich edukacyjnym rozwojem - popularyzacja fenomenu 
nacjonalistyczną postać — ,japońska etyka, zachodnia technologia” (jap. wakon $y \overline{o s} a i)^{42}$.

Aby zrozumieć zmianę w postawie Japończyków pod koniec XIX wieku, należy pamiętać o okolicznościach zainicjowania rewolucji Meiji. W 1853 roku, w chwili otwarcia na świat i przełamania polityki izolacji, Japonia była państwem feudalnym, które gospodarczo, technologicznie i wojskowo znacząco ustępowało europejskim mocarstwom oraz Stanom Zjednoczonym. Przykład słabych i podzielonych Chin, które uległy obcym armiom i stały się państwem quasi-kolonialnym, najbardziej przemawiał do japońskich polityków i dowodził konieczności przeprowadzenia błyskawicznych reform. Reformy te nie mogły zostać zapoczątkowane przez ród Tokugawa, który przez ostatnie dwa wieki doprowadził do zamknięcia Japonii na świat i zachodnią technologię. Decydując się na bunt przeciwko szogunatowi i restaurację władzy cesarskiej w 1868 roku, japońskie klany liczyły nie tylko na modernizację, lecz także na powrót do historycznych korzeni kraju i jego odnowę moralną. W pierwszych latach panowania cesarza Mutsuhito Japonia dokonała znaczących postępów, które obejmowały m.in. umocnienie władzy centralnej, przekształcenie aparatu administracyjnego w kierunku nowoczesnego modelu, zwiększenie wpływów do skarbca państwowego, a także stworzenie zrębów silnej armii lądowej i marynarki wojennej. Groźba kolonizacji kraju została zażegnana, dlatego też elity rządzące postanowiły kontynuować przyspieszony rozwój, lecz nie za cenę utraty własnej tożsamości narodowej. Pomimo przyjęcia zachodnich wzorców u japońskich reformatorów dostrzegalny był etnocentryzm - przekonanie o wyższości Japonii nad pozostałymi krajami. Zachodnia technologia miała zostać wykorzystana ściśle instrumentalnie w celu zrównania siły Cesarstwa z mocarstwami kolonialnymi. Gdy w końcu Japonia znacząco wzmocniła swoją pozycję na arenie międzynarodowej, elity rządzące nie zamierzały podążać za demokratycznymi wzorcami i zaczęły skłaniać się w stronę „samurajskiego autorytaryzmu”, który funkcjonował w kraju przez ostatnie dwa wieki ${ }^{43}$.

Program modernizacji państwa przy jednoczesnym zachowaniu przez niego tożsamości narodowej został oparty o doktrynę kokutai, która miała gwarantować zachowanie ,jedności narodowej” w trudnych dla Japonii czasach. Pojęcie kokutai było jednak w tamtym okresie ciągle nazbyt ogólne i wykorzystywano je zwykle do uzasadniania polityki władz oraz do zapewnienia stabilizacji wewnętrznej poprzez bezwzględną lojalność poddanych wobec boskiego cesarza.

nauk zachodnich jako pośrednika do nauk o wojskowości w schytkowym okresie szogunatu), 教職研 究 (Kyōshoku kenkyū — pol. „Przegląd Nauczycielski”) 2008, no 1, s. 1-23.

42 J.A. Josephson, The Invention of Religion in Japan, Chicago 2012, s. 108; Sanseido, 新明 解四字熟語辞 (Shin Meikai Yoji Jukugo Jiten - pol. Nowy Stownik Japońskich Czteroznakowych Wyrażeń Idiomatycznych), Tōkyō 2007, s. 630.

43 P. Varley, op. cit., s. 266. 


\section{Kokutai w okresie przejściowym - od schyłku ery Meiji aż do końca ery Taishō}

Okres od 1889 do 1925 roku, obejmujący swoim zasięgiem schyłek ery Meiji i niemalże całą erę Taishō, charakteryzował się wzrostem nastrojów nacjonalistycznych i antyliberalnych. Pomimo stopniowego powrotu do historycznego etnocentryzmu zachodnie wzorce demokratyczne były w Japonii tolerowane, a nawet uważane za pożądane, głównie na oficjalnym szczeblu ${ }^{44}$. Stopniowy odwrót od westernizacji był jednak widoczny na wszystkich płaszczyznach funkcjonowania państwa. Po ponad 25 latach pobierania nauk od zagranicznych prawników, mając już pewne doświadczenie w zakresie kodyfikacji prawa, Japończycy zdecydowali się otworzyć pierwszą szkołę prawa japońskiego. Zainteresowanie dawnymi prawami Japonii i ich wpływem na postępującą kodyfikację okazało się wielkie. Na przełomie XIX i XX wieku Japończycy odkryli, iż modernizacja systemu prawa, choć jest niezbędna, może przybrać różny kształt, niekoniecznie odrzucający wiekowe tradycje i zwyczaje. Umownie przyjmuje się, że etap japońskiej jurysprudencji rozpoczął się w 1916 roku, kiedy to po raz pierwszy w historii japoński profesor, Naojirō Sugiyama, objął stanowisko wykładowcy prawa francuskiego na Uniwersytecie Tokijskim ${ }^{45}$.

Przekonanie o wyższości Japonii nad pozostałymi krajami było początkowo charakterystyczne jedynie dla japońskich elit rządzących krajem. Już na przełomie XIX i XX wieku Ministerstwo Edukacji wprowadziło do szkół podręczniki promujące polityczną indoktrynację dzieci, której celem było wychowanie nowego pokolenia żołnierzy cesarza, gardzących życiem każdego przeciwnika, w szczególności wrogów, do których w tamtym czasie zaliczali się Chińczycy i Rosjanie ${ }^{46}$. W ówczesnych podręcznikach szkolnych do języka japońskiego, historii, geografii, a nawet matematyki dostrzegalne są przekazy zawierające elementy ideologii kokutai - wyjątkowości dziejów Japonii na tle całego świata i obowiązku bezwarunkowego posłuszeństwa poddanych wobec cesarza ${ }^{47}$. Doktryna kokutai stanowiła podstawę promowania nacjonalistycznych koncepcji i konieczności stworzenia przestrzeni życiowej dla Japończyków w Azji Wschodniej.

Wraz ze śmiercią cesarza Mutsuhito w 1912 roku i wstąpieniem na tron Yoshihito w Japonii rozpoczęła się era Taishō, która charakteryzowała się demokratyzacją japońskiej polityki i stabilizacją wewnętrzną przed wielkim załamaniem, jakim był światowy kryzys gospodarczy w 1929 roku. Przesłanek tymczasowej demokratyzacji kraju można doszukiwać się w czynnikach zarówno

44 J.E. Power, The Japanese Constitution and the Militarists, „Pacific Affairs” 1942, no 15, s. $189-190$.

45 Y. Noda, Comparative Jurisprudence in Japan: Its Past and Present, part I, s. 215.

46 S. Ineaga, The Pacific War 1931-1945, New York 1978, s. 24.

47 日本教科書近代編 (Nihon Kyōkasho Kindaihen — pol. Japońskie podręczniki, wersja współczesna), t. 18-19, red. T. Kaigo, Tōkyō 1963. 
zewnętrznych, jak i wewnętrznych. Japonia uczestniczyła w I wojnie światowej po stronie państw ententy, licząc na przejęcie niemieckich kolonii na Oceanie Spokojnym. Poza trwającym od 1902 roku układem sojuszniczym z Wielką Brytanią bliskie związki polityczne z demokratyczną Francją i Stanami Zjednoczonymi miały charakter koniunkturalny. Japońscy politycy i dyplomaci byli częstymi gośćmi na zachodnich salonach, gdzie traktowano ich jako równorzędnych partnerów i sojuszników przeciwko autorytarnej i militarystycznej II Rzeszy. Współpraca z mocarstwami kolonialnymi i Stanami Zjednoczonymi owocowała wymianą myśli na wielu płaszczyznach i stała się kolejnym etapem otwarcia Japonii na świat. Japońscy politycy byli naocznymi świadkami demonstracji siły państw demokratycznych, które doprowadziły do rozpadu wieloetnicznych Austro-Węgier i Imperium Osmańskiego, a także upokorzyły autorytarne cesarskie Niemcy.

Jednocześnie był to okres, w którym interpretacja Konstytucji Meiji zbliżyła się znacząco w kierunku demokratycznym. Jak zauważa Antoni Kość, japońska ustawa zasadnicza od samego początku była kompromisem pomiędzy teokratycznym absolutyzmem a nowoczesnym, zachodnim konstytucjonalizmem połączeniem zasady monarchii konstytucyjnej typu niemieckiego i teorii prawa boskiego w ekstremalnej formie ${ }^{48}$. Swobodna interpretacja konstytucji doprowadziła także do redefinicji terminu kokutai, który nie akcentował już tak elementów teokratyczno-nacjonalistycznych, lecz skupiał się na zdefiniowaniu pojęcia japońskiej suwerenności. W wydanej w 1924 roku monografii zatytułowanej „Cesarska Konstytucja” Shinkichi Uesugi wspominał: „Nasza polityka państwowa [kokutai — przyp. M.A.P] przewiduje, iż suwerenność jest powiązana jedynie z osobą cesarza, podczas gdy polityka państwowa Stanów Zjednoczonych utożsamia suwerenność z ludem, obywatelami"49. Demokratyzacja japońskiego życia politycznego w latach 1912-1925 była ściśle związana z korzyściami, jakie Japonia czerpała w związku z uczestnictwem w I wojnie światowej. Można zaliczyć do nich przejęcie niemieckich kolonii na Oceanie Spokojnym, a także przyspieszony rozwój gospodarczy. Wzrost zatrudnienia, poprawa warunków bytowych, a także szacunek społeczności międzynarodowej wobec Japonii sprawiły, że postawy radykalne, w tym ideologia kokutai, ustąpiły miejsca zachodniej demokracji.

Szczególne znaczenie dla dalszego rozwoju koncepcji kokutai w okresie przejściowym miał traktat wersalski, który stanowił o porządku świata po I wojnie światowej. Jego postanowienia stały w zgodzie z głoszonymi od lat poglądami japońskiego lingwisty, Kazutoshiego Uedy, który nauczał o związkach pomiędzy państwowością a językiem narodowym. Choć Japończyk nie uważał siebie za zwolennika nacjonalizmu, jego wizja dotycząca istoty państwowości stała się popularna wśród stronników autorytaryzmu i japońskiego szowinizmu. Ueda głosił, iż każde państwo składa się z czterech filarów: ziemi, „,rasy” w rozumieniu

48 A. Kość, op. cit., s. 85.

49 S. Uesugi，帝国憲法 (Teikoku Kempō- pol. Konstytucja Cesarska), Tōkyō 1924, s. 47. 
ludzi określonej narodowości, jedności i systemu prawa. Jedność została przez niego scharakteryzowana jako wspólne zwyczaje, historia, polityka, religia, język i edukacja ${ }^{50}$. Formułując te tezy, Ueda nie zamierzał tworzyć obiektywnych przesłanek lub praw powstawania państw, lecz miał na celu wykreowanie modelu państwa idealnego i przekonanie swoich słuchaczy, że Japonia doskonale wpisuje się $\mathrm{w}$ ten obraz ${ }^{51}$. Kolejnym istotnym elementem wyjątkowości Japonii miał być wspólny język, który Ueda przyrównywał do tej samej krwi płynącej w różnych ciałach $^{52}$. Idea utożsamiania państwa z żywym organizmem nie była wyłącznie pomysłem Uedy. Do przedstawicieli tzw. doktryny „organicznego kokutai” należał również Yoshio Yamada, który w swojej pracy pt. Wprowadzenie do japońskiego kokutai, wydanej w 1910 roku, pisał:

Kokutai to ciało państwa. Człowiek także posiada ciało. Człowiek jest określonym bytem. Jeżeli patrzeć na to pod kątem fizycznym, jest to odrębny organizm. Jeżeli patrzeć na to pod kątem chemicznym, jest to organizm składający się z chemicznych pierwiastków. Jeżeli zaś patrzeć na to pod kątem biologicznym, jest to organizm składający się z wielu komórek ${ }^{53}$.

Jako przeciwieństwo Japonii, symbolu silnej państwowości, reprezentanci doktryny „organicznego kokutai” w swoich wykładach najczęściej wskazywali wieloetniczne Austro-Węgry, w których różne narodowości reprezentujące inne wartości, mające odrębną kulturę i historię, a przede wszystkim komunikujące się innymi językami, doprowadziły do upadku państwa ${ }^{54}$. Choć przyczyny rozpadu Austro-Węgier były o wiele bardziej złożone, doktryna „organicznego kokutai” zyskała po I wojnie światowej wielu zwolenników, także wśród elit intelektualnych, które wpłynęły później na kierunek japońskiej polityki.

\section{Kryzys demokracji Taishō i powrót do tradycyjnego kokutai}

Od samego początku demokracja ery Taishō stanowiła dla zwolenników niepodzielnej władzy cesarskiej słabość i chorobę Japonii. Interpretacja Konstytucji Meiji, która zezwalała na ograniczanie kokutai, a więc suwerenności państwa,

50 N. Ochiai, K. Ueda, Y. Haga, S. Fujioka, 明治文学全集44 (Meiji bungaku zenshū 44 pol. Kompletna Kolekcja Literatury Meiji 44), Tokyo 1968, s. 108.

51 L. Yeounsuk, The Ideology of Kokugo: Nationalizing Language in Modern Japan, Honolulu 2010, s. 89.

52 N. Ochiai, K. Ueda, Y. Haga, S. Fujioka, op. cit., s. 109-110.

53 S. Yamada, 大日本国体概論 (Dai Nippon Kokutai Gairon - pol. Wprowadzenie do Japońskiego Kokutai), Tōkyō 1910, s. 5-12.

54 N. Ochiai, K. Ueda, Y. Haga, S. Fujioka, op. cit., s. 109-110. 
przez seitai, czyli zmieniające się rządy, miała ich zdaniem doprowadzić do upadku państwa i jego podporządowania zachodnim mocarstwom. Już w 1922 roku odbyła się konferencja waszyngtońska, która, ustalając limity całkowitej wyporności okrętów liniowych po I wojnie światowej w celu ograniczenia zbrojeń, zaliczała Japonię do państw drugiej kategorii, zaraz po Stanach Zjednoczonych i Wielkiej Brytanii, lecz przed Francją i Włochami ${ }^{55}$. Choć był to dla Japonii wielki awans od czasów przełamania izolacji międzynarodowej, japoński rząd, który podpisał traktat, został skrytykowany przez środowiska nacjonalistyczne za ignorowanie narodowych interesów i ambicji ${ }^{56}$.

W dniu 1 września 1923 roku Japonia doświadczyła niespodziewanie olbrzymiej katastrofy naturalnej. Trwające zaledwie 10 minut trzęsienie ziemi na Nizinie Kantō, na której leży Tokio i wiele sąsiadujących z nim miast, spowodowało śmierć ponad 105 tys. ludzi, zniszczyło około 372 tys. budynków i wyrządziło straty finansowe, których do dzisiaj nie udało się precyzyjnie ustalić ${ }^{57}$. Skutkiem tego wydarzenia był pierwszy od czasów restauracji władzy cesarskiej kryzys gospodarczy, który dotknął całą Japonię i wpłynął na radykalizację poglądów społeczeństwa. Niektórzy Japończycy odebrali katastrofę jako karę boską za odstąpienie od tradycyjnych wartości i przyswojenie zachodnich wzorców politycznych i kulturalnych ${ }^{58}$. Choć nie ma dowodów na bezpośredni wpływ wielkiego trzęsienia ziemi na Nizinie Kantō na zmiany poglądów wśród członków rządu, rok 1923 stanowił ważny moment w historii politycznej Japonii.

Schyłek ery Taishō charakteryzował się powrotem do nacjonalistycznej interpretacji terminu kokutai. W dniu 12 maja 1925 roku, wykorzystując słabość oraz chorbę cesarza Yoshihito, gabinet kierowany przez Takaakiego Katō doprowadził do wejścia w życie Prawa Ochrony Porządku Publicznego (jap. Chian ’ijihō). Głównym pomysłodawcą tego aktu prawnego był ówczesny Minister Sprawiedliwości, Ki’ichirō Hiranuma, późniejszy premier Japonii, skazany podczas Procesu Tokijskiego na karę dożywotniego pozbawienia wolności w związku z popełnionymi przez Japończyków zbrodniami wojennymi w wojnie z Chinami (1937-1945). Prawo Ochrony Porządku Publicznego zakładało, że każdy, kto tworzył lub z pełną świadomością należał do organizacji naruszającej „,narodową politykę" lub system własności prywatnej, podlegał karze pozbawienia wolności

55 Conference on the Limitation of Armament, Washington, November 12 1921-February 6 1922, http://www.ibiblio.org/pha/pre-war/1922/nav_lim.html (dostęp: 10.10.2016).

56 Zob. M. Suekuni, S. Takano, Senshi Sōsho (kan 31), 海軍軍戦備 $<1>$ 昭和十六年十一ま で (Kaigun Gunsembi (1): Shōwa Jūrokunen Jüichigatsu Made — pol. Przygotowania marynarki wojennej do wojny do listopada 1941 roku), Tōkyō 1969, s. 21-56.

57 T. Moroi, M. Takemura, 関東地震（1923年9月1日）による被害要因別死者数の推定 (Kantō Jishin — 01.09.1923 in yoru higai yōin betsu shisha kazu no suite — pol. Szacunek liczby ofiary spowodowanych przez trzęsienie ziemi na Nizinie Kantō), ,Journal of Japan Association for Earthquake Engineering" 2004, vol. 4, no 4, s. 24.

${ }^{58}$ M. Lisiecki, op. cit., s. 61. 
lub ciężkich robót nieprzekraczających 10 lat ${ }^{59}$. Poprzez odwołanie do doktryny kokutai rząd miał na celu uciszenie opozycji wewnętrznej, w szczególności organizacji popierających idee socjalistyczne, komunistyczne i anarchistyczne. Przepisy Prawa Ochrony Porządku Publicznego zostały jednak sformułowane na tyle ogólnie, iż karze podlegali nie tylko członkowie lewicowych organizacji, ale każdy, kto sprzeciwiał się ,narodowej polityce" ${ }^{60}$. Pod pretekstem naruszania „charakteru narodowego” 15 marca 1928 roku, trzeciego roku panowania cesarza Hirohito, na polecenie rządu japońska policja aresztowała około 1600 działaczy związanych lub podejrzanych o współpracę z ruchami komunistycznymi i socjalistycznymi. Jeszcze w czerwcu tego samego roku nowy rząd, kierowany przez Gi'ichiego Tanakę, znowelizował ustawę prewencyjną, zaostrzając sankcje karne, które od tamtej pory wynosiły od 10 lat aż do dożywotniego pozbawienia wolności ${ }^{61}$. Choć japoński premier uspokajał, iż prawo skierowane jest głównie przeciwko ruchom rewolucyjnym, które doprowadziły do upadku carskiej Rosji, jego rząd otrzymał w praktyce możliwość zwalczania wszelkich przejawów opozycji wobec władz lub niezadowolenia społecznego. Nowelizacja została ponadto szeroko omówiona w Memorandum zmian, w którym wskazywano analogiczne przepisy w systemach prawych Niemiec, Wielkiej Brytanii, Francji, a nawet Stanów Zjednoczonych ${ }^{62}$. Pomimo zapewnień o prewencyjnym charakterze ustawy od 1925 do 1945 roku łącznie około 70000 ludzi zostało aresztowanych pod zarzutem naruszania Prawa Ochrony Porządku Publicznego. Co prawda jedynie $10 \%$ z nich doczekało sądowego wyroku ${ }^{63}$, lecz wśród poszkodowanych znalazło się wiele niewinnych osób, którym odmówiono prawa do jakiejkolwiek krytyki rządu i prowadzonej przez niego polityki.

W 1926 roku tron po zmarłym Yoshihito objął jego syn, Hirohito, znany później jako cesarz Shōwa. Lata 1926-1937 były okresem, w którym w Japonii ostatecznie zwyciężyła ideologia nacjonalistyczna i szowinistyczna. Brak doświadczenia politycznego młodego cesarza od samego początku był wykorzystywany przez wojskowych, w szczególności oficerów armii lądowej (jap. Dai

59 治安維持法, 大正14年法律第46号 (Chian'ijihō, Taishō 14-nen Hōritsu Dai 46-go — pl. Prawo Ochrony Porządku Publicznego, Akt Prawny Nr 4614 roku ery Taishō), https://www.digital. archives.go.jp/DAS/meta/listPhoto?LANG=default\&BID=F0000000000000006687\&ID=M00000 00000001757587\&TYPE $=\& N O=($ dostęp: 12.10 .2016$)$.

60 J. L. McClain, op. cit., s. 390; Y. Okudaira, 治安維持法小史 (Chian'ijihō shōshi- pol. Krótka historia Prawa Ochrony Porządku Publicznego), Tōkyō 2006, s. 53-56. Zob. I. Kita, 国体 論及び純正社会主義 (Kokutairon oyobi junsei shakaishugi - pol. Kokutai i czysty socjalizm), Kyōto 2007.

61 治安維持法中改正ノ件, 昭和3年勅令第129号 (Chian'ijihō chūkaisei no ken - pol. Przepisy rewidujące Prawo Ochrony Porządku Publicznego, Edykt Cesarski Nr 1293 roku ery Shōwa), https://www.digital.archives.go.jp/das/image/M2008121117141425801 (dostęp: 12.10.2016).

62 T. Nagai, 転向手記 (Tenkō shuki — pol. Memorandum zmian), Tōkyō 1935.

63 Zob. 文化評論, 1976年臨時増刊号 (Bunka Hyōron, 1976-nen rinjizōkan gō — pol. „Krytyka Kulturalna”, nr specjalny z 1976 roku). 
Nippon Teikoku Rikugun), którzy byli zwolennikami absolutyzmu połączonego ze skrajnym militaryzmem. W 1929 roku Japonię dotknął drugi w ciągu dekady kryzys gospodarczy. Wielka depresja w Stanach Zjednoczonych, a później także w Europie stała się dla zwolenników władzy absolutnej pretekstem do krytyki demokracji i gospodarki wolnorynkowej jako prowadzących do destabilizacji państwa. Popularność antydemokratycznych haseł i postulat powrotu do korzeni zyskały poparcie części społeczeństwa, której postawa radykalizowała się w związku z pogarszającą się sytuacją materialną. Niezadowolenie społeczne, które mogło obrócić się przeciwko decydentom, zostało wykorzystane przez armię do umocnienia własnej pozycji w państwie. Pozbawione autorytetu rządy gabinetowe traciły stopniowo kontrolę nad społeczeństwem i siłami zbrojnymi. Szczególnym nieposłuszeństwem charakteryzowała się młoda kadra podoficerska skupiona wokół Frakcji Cesarskiej Drogi (jap. Kōdōha), która żądała usunięcia starych i skompromitowanych polityków oraz restauracji władzy cesarskiej. Coraz częściej w japońskim życiu politycznym pojawiał się postulat powrotu do tradycyjnego cesarskiego autorytaryzmu. Formułą gwarantującą pomyślność kraju w trudnych czasach miała stać się „odnowiona” doktryna kokutai, którą zamierzano oczyścić z demokratycznych naleciałości. Poprzez odwoływanie się do hasła odbudowy kraju, lansowanego przez słynnego japońskiego nacjonalistę, Ikkiego Kitę, działacze skupieni wokół wojskowych radykałów zamierzali doprowadzić do ponownej restauracji władzy cesarskiej i reformy kraju, która miała obejmować głęboką odnowę moralną. Formułując postulat zniszczenia zdrajców, za których uważano polityków popierających zachodnie systemy zarządzania państwa, uważali oni siebie za jedynych obrońców idei kokutai i całego systemu cesarskiego ${ }^{64}$.

Kōdōha swoje największe wpływy miała w Armii Kwantuńskiej (jap. Kantōgun), którą utworzono w 1907 roku do obrony japońskich interesów w Mandżurii. Przed północą 18 września 1931 roku jej oficerowie, dążąc do zabezpieczenia i poszerzenia japońskiej strefy wpływów, sprowokowali incydent, który przerodził się $\mathrm{w}$ regularne działania wojenne, skutkujące zajęciem trzech chińskich prowincji w ciągu zaledwie pięciu miesięcy. Samowolnej akcji Armii Kwantuńskiej nie zdołał powstrzymać nawet Cesarski Sztab Generalny (jap. Sambō-hombu), który przystał do polityki faktów dokonanych. Za agresywną politykę Japonię potępiła społeczność międzynarodowa. Fala krytyki, która spłynęła po utworzeniu przez Japończyków marionetkowego państwa Mandżukuo (jap. Manshū-koku), sprawiła, że w 1933 roku Japonia zdecydowała się opuścić Ligę Narodów. Choć rok później tron Manshū-koku objął cesarz Puyi z mandżurskiej dynastii Qing, jego państwo było kolonią administrowaną przez japońskich oficerów. Mandżurskie ziemie, bogate w rudy żelaza, węgiel kamienny i ropę naftową, miały zostać skolonizowane przez Japończyków, co

${ }^{64}$ E. Pałasz-Rutkowska, General ..., s. 56. 
rozwiązałoby problem przeludnienia macierzystych wysp. Manshū-koku było traktowane przez japoński rząd nie tylko jako państwo buforowe, lecz również jako poligon doświadczalny dla koncepcji gospodarki planowanej i strefa specjalnych wpływów japońskich przedsiębiorców ${ }^{65}$.

Rok 1931 i zajęcie Mandżurii wyznaczają w historii Japonii nowy okres akceptacji nacjonalizmu i militaryzmu, które skierowały kraj w stronę ekspansji w Azji Wschodniej, skutkującej ostatecznie konfliktem z aliantami i całkowitą klęską w II wojnie światowej. Za prowadzenie agresywnej polityki wobec Chin na początku lat 30. odpowiedzialna była determinacja skrajnej prawicy, która widziała w Japończykach rasę panów predestynowaną do zebrania „ośmiu rogów świata pod jednym dachem" (jap. hakkō ichiu). Jednocześnie w kraju rozpoczęły się przygotowania do oczyszczenia rządu z demokratycznych i liberalnych wpływów oraz stworzenia społeczeństwa popierającego działania japońskiej armii. $\mathrm{W}$ połowie lat 30 . zwolennicy ustanowienia cesarskiej dyktatury wspieranej przez wojskowych doradców stworzyli „Ruch Oczyszczania Kokutai” (jap. Kokutai Meichō Undō) z zamiarem walki z demokratyczną interpretacją tego terminu przez polityków i teoretyków prawa. Szczególnej krytyce poddano prace uznanego konstytucjonalisty, Tatsukichiego Minobe, który w ostatnim roku panowania cesarza Mutsuhito przedstawił koncepcję pozycji cesarza jako głowy państwa, czyli organizacji stworzonej przez naród ${ }^{66}$. Teoria ta stała się tematem plenarnej sesji Izby Panów 18 lutego 1935 roku, kiedy to została zaatakowana przez członka parlamentu, generała porucznika Cesarskiej Armii Japońskiej, zasłużonego weterana wojny z Rosją w latach 1904-1905, Takeo Kikuchiego. Nazwał on wprost dorobek Minobe raczkującą rebelią, która przybiera coraz bardziej znamiona ewidentnej zdrady. Używając określeń „naukowy dyletant” i „buntownik”, miał na celu zdyskredytowanie japońskiego konstytucjonalisty w oczach innych polityków. Następnego dnia odbyło się dobrowolne, nadzwyczajne, wspólne posiedzenie Izby Reprezentantów i Panów, podczas którego zbadano zaistniałą wcześniej sytuację, po czym zdecydowano się wydać oficjalną rezolucję odrzucającą interpretację wskazującą cesarza jako głowę państwa. W odpowiedzi 25 lutego Minobe wygłosił publiczne oświadczenie w Izbie Radców podczas plenarnej sesji, wyrażając swoje oburzenie i jednocześnie głęboki żal z powodu bezprecedensowego ataku personalnego. Analizując po kolei przepisy konstytucji dotyczące cesarza, przekonywał, iż jego teoria stoi w zgodzie z prawem, cesarz zaś zajmuje w niej zaszczytne miejsce głowy państwa i narodu, jak również osoby, która sprawuje specjalną kontrolę nad sytuacją w kraju ${ }^{67}$.

65 W.G. Beasley, Japanese Imperialism 1894-1945, Oxford 1999, s. 195-197; M. Kołodziejski, Takahashi Korekiyo 1854-1936 a gospodarka międzywojennej Japonii, Warszawa 2006, s. 126.

66 T. Minobe, 憲法講話 (Kempō Kōwa - pol. Wykład o Konstytucji), Tōkyō 1921, s. 12-25.

67 T. Minobe,「一身上の弁明」演説: 現代語訳 (,Isshinjō no benmei” enzetsu: gendai goyaku — pol. Przemowa pt. „,moje wyjaśnienie”: wspótczesne tlumaczenie), dokument elektroniczny. 
Spór nad interpretacją kokutai miał podłoże ściśle ideologiczne. Zdaniem japońskich polityków wspierających koncepcję ,jedności narodowej” konstytucja nie mogła nadawać cesarzowi mniejszych praw niż miał w rzeczywistości jako potomek bogów. Obrady parlamentu, które przeszły do historii pod nazwą „,incydentu o statusie cesarza w państwie" (jap. Tennō kikansetsu jiken), stanowią symboliczny kres demokracji w japońskim życiu politycznym i początek szintoistycznego nacjonalizmu ery Shōwa. Już 3 sierpnia 1936 roku gabinet Keisuke Okady, by zapobiec dalszym dyskusjom politycznym wokół pozycji cesarza w państwie, wydał rządową deklarację dotyczącą interpretacji kokutai. Podkreślano w niej boskie pochodzenie cesarza, odrzucając jednocześnie jakąkolwiek możliwość ograniczania jego władzy przez rząd i konstytucję ${ }^{68}$. Interpretacja Minobe w żaden sposób nie została wzięta pod uwagę jako godząca w majestat cesarza. 19 sierpnia Japończyk zrezygnował z mandatu Izby Radców, wkrótce zaś jego dzieła z zakresu prawa konstytucyjnego objęto zakazem druku. W październiku gabinet Okady pod naciskiem wojskowych i radykałów wydał kolejne rządowe oświadczenie o boskim statusie cesarza w państwie, nadrzędnej mocy prawnej cesarskich reskryptów nad konstytucją, a także braku możliwości kontroli cesarza przez demokratycznie wybrany parlament i gabinet ${ }^{69}$.

W 1935 roku w japońskim parlamencie ostatecznie zwyciężyły siły, które otwarcie piętnowały podważanie „charakteru narodowego”, w szczególności wyjątkowego statusu cesarza w państwie i społeczeństwie. Zwolennicy oczyszczenia kokutai z elementów demokratycznych i liberalnych za wzór przyjęli poglądy teoretyka buddyzmu, zadeklarowanego zwolennika skrajnego nacjonalizmu, Chigaku Tanako, który nauczał o boskim pochodzeniu cesarza:

Nie trzeba wspominać o tym, iż Japonia jest ziemią utworzoną przez bogów, jest boską ziemią [...]. Jest to sprawą najwyższej wagi dla władców tej ziemi, aby oddać bogom to, co zostało od nich wzięte [...]. Cesarze, potomkowie bogów, którzy przybierają ludzkie postacie, są przywódcami ziemi należącej do bogów. Tron nie został stworzony przez pierwszego cesarza Jinmu, lecz został odziedziczony, pokolenie po pokoleniu, po bogini słońca z boskich lat ${ }^{70}$.

Pogląd o konieczności podkreślania boskiego pochodzenia cesarza i jego roli w państwie był jedynie elementem większej doktryny, która nakazywała podporządkowanie całego społeczeństwa „polityce narodowej”. Poglądy w znacznej mierze nawiązywały do wykładów głoszonych przez zmarłego w 1929 roku profesora prawa na Uniwersytecie Tokijskim, radykalnego nacjonalisty, Shinkichiego

68 国体明徵二関スル政府声明経過，1935年8月3日 (Kokutai Meichō ni kansuru Seimei Keika 03.08.1935 - pol. Wprowadzenie deklaracji w sprawie interpretacji kokutai $\mathrm{z}$ dnia 3 sierpnia 1935 r.), http://www.archives.go.jp/ayumi/kobetsu/s10_1935_02.html (dostęp: 20.10.2016).

69 国体明徵二関スル再声明 フ通牒ス, 1935年10月15日 (Kokutai Meichō ni kansuru Saiseimei o Tsūchōsu 15.10.1935 - pol. Ponowna notyfikacja w sprawie interpretacji kokutai z dnia 15 października 1935 r.), https://www.jacar.archives.go.jp/aj/meta/MetSearch.cgi (dostęp: 20.10.2016).

70 G. Rosenkranz, Shinto - der Weg der Götter, Wachtendonk 2003, s. 109. 
Uesugiego, który przekonywał, że „poddani nie mają opinii różnej od tej, którą posiada cesarz” "71, a także, iż „państwo jest uosobieniem największej cnoty”72.

Japońscy teoretycy ideologii kokutai mogli liczyć na wsparcie środowisk armijnych, które w obaleniu japońskiej demokracji widziały szansę na przejęcie władzy w państwie jako bezpośredni wykonawcy woli cesarza, a także realizację imperialnych planów podboju Azji Wschodniej. Politycy, naukowcy i wojskowi popierający ekspansję terytorialną stworzyli w państwie sieć powiązań, które promowały program rozbudowy sił zbrojnych i postulowały wprowadzenie kolejnych ograniczeń swobód obywatelskich na rzecz zgodnej ,polityki narodowej”. Już w 1937 roku armia lądowa i marynarka wojenna stały się beneficjentami 70\% całorocznego budżetu, a pierwsze inwestycje w Mandżurii zaczęły przynosić pożytek gospodarce japońskiej, która rozpoczęła proces dozbrajania i zwiększania armii ${ }^{73}$.

\section{Ostatnie stadium kokutai - Kokutai no hongi i wojna na Pacyfiku}

Od czasów wydania Cesarskiego Reskryptu o Wychowaniu sytuacja polityczna Japonii znacząco się zmieniła. Z państwa, którego celem jest dogonienie mocarstw kolonialnych i obrona własnej niezależności, cesarstwo przeistoczyło się w potęgę aspirującą do dominacji w Azji Wschodniej. W związku z ekspansjonistycznymi planami oraz mającymi miejsce w 1935 roku dyskusjami w parlamencie japońscy politycy dostrzegli potrzebę ponownego zdefiniowania terminu kokutai. Na stworzenie oficjalnej wykładni, która tłumaczyła społeczeństwu wprowadzenie autorytarnych rządów silnej ręki szczególnie nalegali militaryści, sugerując, że jest to jedyna szansa na odbudowę kraju i jego pomyślności poprzez kultywowanie słusznych tradycji narodowych. Jedyną siłą, która mogła utrzymać dyscyplinę w kraju, miała być armia, która na mocy Konstytucji Meiji pozostawała pod zwierzchnictwem cesarza. Choć to rząd decydował o rocznym budżecie i środkach przeznaczonych na siły zbrojnie, nie miał on nad nimi żadnej efektywnej kontroli, podczas gdy przedstawiciele armii lądowej i marynarki stanowili część gabinetu. Paradoksalnie również cesarz miał bardzo ograniczony wpływ na działania armii, ponieważ zwyczajowo rzadko ingerował w kierunek polityki obranej przez siły zbrojne. W efekcie tego w latach 30. w Japonii wytworzyła się rzeczywistość, w której armia nie zależała od nikogo, sama jednak rościła sobie prawo do bezpośredniego wykonywania poleceń cesarza $^{74}$. W praktyce cesarz akceptował każdą decyzję sił zbrojnych jako wyraz

71 Zob. T. Ida, 上杉慎吉: 天皇制国家の弁証 (Uesugi Shinkichi: tennōsei kokka no bensho— pol. Uesugi Shinkichi: dowód na państwowy system cesarski), Tōkyō 1989, s. 156.

72 Zob. S. Uesugi, 国家新論 (Kokka shinron — pol. Nowa teoria o państwie), Tōkyō 1921.

73 H.P. Willmott, Empires in the Balance: Japanese and Allied Pacific Strategies to April 1942, Annapolis 2008, s. 53.

74 E. Pałasz-Rutkowska, Działania..., s. 39. 
woli narodu oraz jego elit politycznych i wojskowych. Hasło kokutai stało się dla militarystów słowem kluczem, na którym zbudowano całą machinę propagandową, mającą na celu przekonanie Japończyków, iż autorytarne rządy wojskowych służą odnowie moralnej w kraju, jego nieograniczonej potęgi, której pragnie cesarz ojciec całego narodu.

Po raz kolejny w historii obiektem nacjonalistycznej i szowinistycznej propagandy stały się dzieci i młodzież w wieku szkolnym, które miały stanowić o pomyślnej przyszłości kraju. Rolę propagowania wartości narodowych powierzono Ministerstwu Edukacji, które miało za zadanie połączenie funkcji szerzenia narodowej wiedzy (jap. kokumin kyoiku) i narodowej etyki (jap. kokumin dōtoku ${ }^{75}$. Centralną rolę w edukacji narodu miała odegrać doktryna kokutai, której celem była konsolidacja świadomości narodowej Japończyków wokół wspólnych wartości i jednego celu, jakim była hegemonia Japonii w Azji Wschodniej ${ }^{76}$. Począwszy od 1933 roku japońscy ideologowie nacjonalizmu publikowali opracowania dotyczące jedynej słusznej ich zdaniem interpretacji terminu kokutai. Jako przykład można podać prace Yoshio Yamady ${ }^{77}$, a także Sadaichiego Nishikawy ${ }^{78}$, Matajirō Yamazakiego ${ }^{79}$, Yoshirō Sakataniego ${ }^{80}$, a także Shirō Arimoto ${ }^{81}$.

O oficjalnej wykładni kokutai miało jednak zdecydować Ministerstwo Edukacji, które zorganizowało dwa współpracujące z sobą zespoły. Pierwszy zespół, nazwany Komisją Opracowującą, złożony był z czternastu naukowców, głównie związanych z Uniwersytetem Tokijskim i Uniwersytetem w Kioto. Specjalizacje naukowców dotyczyły takich dziedzin, jak: prawo, historia, językoznawstwo, literaturoznawstwo i religioznawstwo. Drugi zespół, nazywany Zespołem Pomocniczym, złożony był z dziesięciu inspektorów powiązanych z rządem, których zadaniem był nadzór nad wynikami badań Komisji Opracowującej. Wskazanie wyczerpującej listy osób, które wzięły udział w pracach nad ministerialnym projektem, jest trudne do ustalenia, ponieważ nie prowadzono wówczas szczegółowych protokołów spotkań i list obecności. Wiadomo jednak, że nad całością prac czuwał szef Biura do spraw Kontroli Myśli, Enkichi Itō, który zasłynął $\mathrm{z}$ wielu ingerencji (na poziomie zarówno ideologicznym, jak i edytorskim)

75 M. Lisiecki, op. cit., s. 68.

76 Ibidem.

77 Y. Yamada, 国体の本義 (Kokutai no hongi - pol. Podstawowe znaczenie charakteru narodowego), Tōkyō 1933; Y. Yamada, 国体の本義に就て (Kokutai no hongi ni tsuite — pol. Odnośnie do podstawowego znaczenia charakteru narodowego), Sendai 1934.

78 S. Nishikawa, 国体の本義と皇道財政 (Kokutai no hongi to kōdō zaisei - pol. Podstawowe znaczenie charakteru narodowego i finanse publiczne cesarskiej drogi), Shimonseki 1935.

79 M. Yamazaki, 憲法と國體の本義 (Kempō to kokutai no hongi — pol. Konstytucja i podstawowe znaczenie charakteru narodowego), Tōkyō 1936.

80 Y. Sakatani, 我が國體の本義 (Waga kokutai no hongi — pol. Nasze podstawowe znaczenie charakteru narodowego), Tōkyō 1936.

81 S. Arimoto, 建国の由来と国体の本義 (Kenkoku no yurai to kokutai no hongi - pol. Źródta powstania państwa i podstawowe znaczenie charakteru narodowego), Tōkyō 1937. 
w propozycjach przedstawionych przez Komisję Opracowującą, co spotkało się z krytyką niektórych naukowców ${ }^{82}$. Ostateczny tekst nowej wykładni kokutai został nazwany Kokutai no hongi, co w przekładzie na język polski oznacza Podstawowe znaczenie charakteru narodowego ${ }^{83}$. Choć w literaturze przedmiotu istnieją pewne dyskusje nad datą wydania dokumentu, japońskie archiwa należące do Ministerstwa Edukacji podają zgodnie 30 marca 1937 roku $^{84}$. Nakład pierwszego wydania wynosił 300 tys. sztuk i został wkrótce rozdystrybuowany do pracowników naukowych i dydaktycznych, a także wszelkich placówek edukacyjnych — od szkół podstawowych aż do uniwersytetów ${ }^{85}$. Bez względu na status szkół - państwowych czy prywatnych — nauczyciele otrzymali polecenie zwrócenia szczególnej uwagi na codzienne nauczanie Kokutai no hongi i jego interpretację w duchu narodowym. Pomimo, iż tekst został skierowany do ogółu ludności Japonii, a w szczególności do młodzieży, został napisany z zachowaniem archaicznych zasad językowych. Znaczną część pracy tworzyły ponadto znaki opisujące historyczne pojęcia z zakresu teorii shintō, które do pełnego rozumienia wymagały specjalistycznego wykształcenia. Oprócz chęci podniesienia Kokutai no hongi do rangi dokumentu państwowego był to zamierzony zabieg mający na celu ograniczanie potencjalnych dyskusji nad jego treścią. Japońscy uczniowie mieli uczyć się o swoich powinnościach wobec cesarza i narodu bez prawa do własnego zdania.

Kokutai no hongi składało się łącznie z 156 stron podzielonych na cztery części: wstęp (jap. shōgen), rozdział pierwszy zatytułowany Kokutai Wielkiej Japonii ew. Kokutai Yamato (jap. Dai Nippon Kokutai), rozdział drugi zatytułowany Manifestacje kokutai w historii narodu (jap. Kokushi ni okeru kokutai no kengen) oraz zakończenie nazwane konkluzjami (jap. gestugo). Rozdział pierwszy dodatkowo podzielono na cztery podrozdziały (1. Założenie państwa - jap. Chōkoku, 2. Największe cnoty - jap. Seitoku, 3. Lojalność wobec cesarza - jap. Shinsetsu, 4. Pokój i prawda - jap. Wa to makoto), zaś rozdział drugi na sześć podrozdziałów (1. Duch integrujący historię narodu — jap. Kokushi o ichikan suru seishin, 2. Ojczyzna i żywot narodu — jap. Kokudo to kokumin seikatsu, 3. Cechy narodu - jap. Kokuminsei, 4. Obrzędy religijne i moralność — jap. Saishi to dōtoku, 5. Kultura narodowa - jap. Kokumin bunka, 6. Polityka, ekonomia i sprawy wojskowe — jap. Seiji, keizai, gunji).

Szersze omówienie treści Kokutai no hongi zasługuje na odrębną pracę, dlatego też niniejsza część artykułu ma na celu wskazanie jedynie najistotniejszych

82 J.O. Gauntlett, R.K. Hall, op. cit., s. 5-10.

83 Tłumaczenie to zostało zaproponowane przez prof. Pałasz-Rutkowską i jest ono zgodnie używane przez polskich japonistów. Przykłady innych prawidłowych przekładów: „Podstawowe zasady kokutai”, „Prawdziwe znaczenie kokutai”, „Ukryte znaczenie kokutai”.

84 國體の本義 (Kokutai no hongi — pol. Podstawowe znaczenie charakteru narodowego), red. Mombushō, Tōkyō 1937.

85 J.O. Gauntlett, R.K. Hall, op. cit., s. 4-5. 
zmian w postrzeganiu kokutai przez japońskie władze. Oprócz powtarzania istniejących od wieków poglądów dotyczących mitycznego stworzenia Japonii przez bogów, interpretacji tego wydarzenia jako dowodu na istnienie narodu wybranego, jak również akcentowania boskiego pochodzenia cesarza z nieprzerwanej linii dynastycznej, Kokutai no hongi zawiera wiele nowych interpretacji, które można sklasyfikować jako nacjonalistyczne, szowinistyczne, militarystyczne, a także nawet socjalistyczne. Znaczącej przebudowie uległy obowiązki poddanych, którzy poza miłością synowską do cesarza, wiernością i zachowaniem harmonii w stosunkach z pobratymcami mieli ślepo wykonywać polecenia władz jako wyraz woli bogów. Szczególny nacisk położono na szerzenie kultury narodowej stojącej w całkowitej opozycji do wzorców zachodnich, a więc demokracji i liberalizmu. Najważniejszym jednak novum w Kokutai no hongi było wskazanie szczególnej misji Japonii w dziejach świata. Misja ta miała polegać na zdominowaniu Azji Wschodniej i „wygonieniu intruzów”, do których zaliczano nieazjatyckie narody. Trzeba przy tym wspomnieć, że również innych Azjatów uważano za gorszych od Japończyków - należy nimi rządzić i wykorzystywać ich do stworzenia potęgi Japonii. Poddani cesarza mieli angażować się po stronie armii nie tylko poprzez poparcie i dobrowolny zaciąg, lecz także przez akceptowanie centralnie sterowanej gospodarki wojennej pochłaniającej większość zasobów państwa. Kokutai no hongi całkowicie odrzuca wolną wymianę myśli i krytykę armii jako element wpływów sił wrogich Japonii. Społeczeństwo o jednolitych poglądach, pracujące na rzecz jednego narodowego celu, miało zbudować potęgę światową, której nie mogło się równać żadne inne państwo, w tym moralnie zepsute Stany Zjednoczone.

Publikacja Kokutai no hongi zbiegła się w czasie z innym ważnym wydarzeniem w historii Japonii. 7 lipca 1937 roku japońskie wojska, wykorzystując słabość cywilnego rządu i jego brak zdecydowania, sprowokowali incydent na Moście Marco Polo, który przerodził się w trwającą ponad osiem lat wojnę z Chinami. Do 1938 roku Japończycy zaangażowali w Chinach około 1,5 miliona żołnierzy, którzy w niespełna osiemnaście miesięcy podbili terytorium o powierzchni ponad $1800000 \mathrm{~km}^{2}$, zamieszkiwane przez około 170 milionów ludzi - prawie trzykrotnie więcej niż liczyła ówcześnie sama Japonia ${ }^{86}$. Pogarda japońskich żołnierzy dla pokonywanych Chińczyków była powszechnym zjawiskiem i doprowadziła do wielu tragicznych zbrodni wojennych, do których należy między innymi mająca miejsce na przełomie 1938 i 1939 roku rzeź od 40 do 300 tys. mieszkańców stołecznego Nankinu ${ }^{87}$.

86 H.P. Willmott, op. cit., s. 55.

87 Rzeczywista liczba ofiar rzezi Nankinu na przełomie 1938 i 1939 roku jest współcześnie trudna do ustalenia. Dane podawane przez naukowców różnią się w zależności od źródeł, z których korzystali, a także obarczone są błędami w szacowaniu. Najmniejsza liczba ofiar, która pojawia się w opracowaniach, to 40 tys., prace wydawane przez agencje chińskiego rządu zaś mówią nawet o 300 tys. zamordowanych mieszkańców miasta. The Nanking Atrocity, 1937-38: Complicating the Picture, red. B.T. Wakabayashi, Oxford-New York 2007, s. 362. 
Pomimo, iż japońscy wojskowi przedstawiali cesarzowi plany ostatecznego pokonania Chin w ciągu kilku miesięcy do incydentu na Moście Marco Polo, wojna ta trwała przez kolejne lata, pochłaniając olbrzymie zasoby gospodarcze i ludnościowe Japonii. Choć Chiny były wówczas państwem słabym i podzielonym politycznie, okazały się zbyt duże, aby mogły zostać podbite i okupowane przez japońską armię. Oprócz tego Japonia miała przeciwko sobie społeczność międzynarodową, która potępiała jej agresję, a w szczególności szokujące zbrodnie wojenne opisywane $\mathrm{w}$ prasie na całym świecie. W związku z negatywnymi perspektywami na szybkie zwycięstwo w 1940 roku Japończycy przedstawili alternatywny plan odcięcia Chin od południa i zakończenia wojny w krótkim czasie. Do tego celu wojskowi zamierzali wykorzystać bazy wojskowe w Indochinach Francuskich, które po pokonaniu Francji przez III Rzeszę stały otworem dla japońskiej armii i marynarki wojennej. Kolejne ekspansywne kroki zaniepokoiły Stany Zjednoczone i w ciągu kolejnego roku doprowadziły do alianckiego embarga na sprzedaż ropy naftowej. Japonia jako kraj uzależniony w $90 \%$ od dostaw tego surowca, musiała wycofać się z Chin lub zdecydować się na kolejną wojnę w celu kontynuowania swoich planów w Azji Wschodniej. Choć gabinet premiera Fumimaro Konoe negocjował jeszcze z Amerykanami warunki wycofania się Japonii z Chin oraz przywrócenia normalnych relacji politycznych i gospodarczych z aliantami, jego starania zostały storpedowane przez wojskowych. Każdy przejaw krytyki wobec armii traktowany był jako naruszenie podstawowych zasad kokutai, toteż cywilny gabinet i siły zbrojne nie zdołały znaleźć wspólnego stanowiska w kwestii porozumienia ze Stanami Zjednoczonymi i ich sojusznikami. Ostatecznie jesienią 1941 roku fotel premiera japońskiego rządu objął generał Hideki Tōjō, dzięki czemu militaryści uzyskali pełnię władzy nad gabinetem i całym japońskim życiem politycznym. Traktując przedłużające się negocjacje z Amerykanami i ich warunki jako upokorzenie Japonii, Tōjō uzyskał zgodę oszukiwanego przez wojskowych doradców cesarza na rozpoczęcie decydującej wojny z mocarstwami zachodnimi o hegemonię w Azji Wschodniej. Wczesnym rankiem 7 grudnia 1941 roku japońskie samoloty z pokładów sześciu lotniskowców zaatakowały podstępnie amerykańską bazę marynarki wojennej w Pearl Harbor na Hawajach, doprowadzając do wybuchu drugiej wojny światowej na Pacyfiku. Wojna ta zakończyła się w 1945 roku całkowitą klęską Japonii, śmiercią milionów cywili i żołnierzy japońskich, olbrzymimi zniszczeniami miast, a także zrzuceniem bomb atomowych na Hiroszimę i Nagasaki. Do ostatniego dnia konfliktu gabinet Kantarō Suzukiego negocjował z Amerykanami warunki kapitulacji, stawiając tylko jeden zasadniczy warunek — obietnicy zachowania przez aliantów kokutai. Kokutai nie było już wówczas traktowane przez rząd zgodnie z oficjalną ministerialną wykładnią z 1937 roku, lecz jako tradycyjny ustrój cesarski, który stanowił najważniejszy element japońskiej tożsamości narodowej. 
O kształcie „ustroju narodowego” miały jednak ostatecznie zdecydować Stany Zjednoczone, które z pełną konsekwencją doprowadziły do bezwarunkowej kapitulacji Cesarstwa Japonii. Choć cesarz kojarzony był ze wszystkimi najgorszymi cechami japońskiego nacjonalizmu i militaryzmu - agresywną polityką wobec sąsiadów, sojuszem z nazistowskimi Niemcami, zbrodniami wojennymi i pogardą wobec wrogów, Amerykanie zdecydowali się zachować Hirohito na tronie. Zmiana japońskiego społeczeństwa w kierunku demokracji i pokojowego współistnienia z innymi narodami nie mogła polegać jedynie na usunięciu głowy państwa, lecz na gruntownej reformie całego systemu. Już w październiku 1945 roku amerykańskie władze okupacyjne zakazały druku i rozpowszechniania Kokutai no hongi, zniesiono również Prawo Ochrony Porządku Publicznego jako akt prawny sprzeczny z podstawowymi prawami człowieka. Ostatnie elementy doktryny kokutai w sferze funkcjonowania państwa zostały zlikwidowane w 1947 roku wraz z wejściem w życie nowej Konstytucji Japonii. Definitywnie zrywała ona z boskim pochodzeniem cesarza, który stawał się głową państwa, Cesarstwa Japonii, które od tej pory było nie wyłączną własnością władcy, lecz wszystkich jego obywateli.

\section{Zakończenie}

Doktryna kokutai przez prawie 200 lat istnienia w japońskim życiu politycznym przeszła gruntowną ewolucję. Początkowo stanowiła ona koncept szkół teoretyków shintō, które w szerzeniu wiedzy dotyczącej mitycznego stworzenia Japonii przez bogów i potwierdzenia boskiego statusu cesarza widziały szansę na reformę kraju i oczyszczenia go z buddyjskich i konfucjańskich wpływów. W dobie kolonizacji świata przez Europejczyków szczególny nacisk został położony na odnowę moralną Japończyków, którzy skupieni wokół jednego celu — powrotu do kokutai - mieli uniknąć losu pozostałych państw regionu. W tym okresie hasło niemające większego wpływu na politykę władz było znane jedynie wśród elit intelektualnych.

Wraz z restauracją władzy cesarskiej i koniecznością modernizacji państwa, w pierwszym etapie rewolucji Meiji doktryna kokutai stała się przedmiotem analiz japońskich prawników i myślicieli, którzy w jej redefinicji dostrzegali szansę na zmianę charakteru państwa i jego otwarcie na świat. Szerzone przez Hiroyukiego Katō i Yukichiego Fukuzawę liberalne i demokratyczne poglądy nie trafiły na podatny grunt, drugi z nich zaś nawet całkowicie porzucił swoje poglądy na rzecz autorytaryzmu. Intensywna modernizacja Japonii w latach 80. i 90. niosła z sobą jedynie przyjmowanie zachodniej technologii, organizacji i prawa, podczas gdy w rzeczywistości elity japońskie tradycyjnie uważały swój kraj za doskonały, gdyż został on stworzony przez bogów. Był to również okres, w którym w japońskim życiu politycznym zwyciężyła myśl promująca zachodnią technologię, lecz 
wschodnią moralność. Gwałtowny wzrost znaczenia Japonii na arenie międzynarodowej, uniknięcie europejskiej kolonizacji i kształtowanie się nowoczesnego narodu sprawiły, że elity rządzące cesarstwem dostrzegły szansę na prowadzenie samodzielnej polityki imperialnej. Próbując zagwarantować sobie posłuszeństwo obywateli, sięgnięto do doktryny kokutai, która oficjalnie miała pełnić funkcję szerzenia patriotycznej postawy i troski o własny naród. Pomimo wejścia w życie Konstytucji Meiji bazującej na europejskich, w szczególności pruskich, wzorcach w społeczeństwie nie dostrzegano suwerena. W myśl doktryny kokutai był nim cesarz, którego jednocześnie utożsamiano z faktem istnienia Japonii.

Czasy I wojny światowej i pierwsze lata po jej zakończeniu przyniosły demokratyzację japońskiego życia politycznego. Poprawa warunków bytowych społeczeństwa oraz fakt współdecydowania o porządku światowym sprawiły, iż na szczeblu państwowym Japończycy odeszli od doktryny, która stała się przeszkodą w dobrych kontaktach z sojusznikami. Sytuację tę zmieniło wielkie trzęsienie ziemi i dwa kryzysy gospodarcze, dzięki którym wpływy w kraju ponownie uzyskali zwolennicy cesarskiego autorytaryzmu i ideologii kokutai jako wyrazu boskich planów wobec Japonii. Dwudziestolecie międzywojenne było również okresem intensywnego zwalczania ideologii uważanych za zagrażające stabilności państwa. Pod pozorem likwidacji organizacji komunistycznych, socalistycznych i anarchistycznych uchwalono prawo umożliwiające pozbawienie wolności każdego, kto sprzeciwi się polityce rządu. Formułą gwarantującą posłuszeństwo obywateli stało się kokutai, które od czasów podkreślania boskiego pochodzenia cesarza i konieczności lojalności wobec niego przybrało charakter niedookreślonego zwrotu umożliwiającego zwalczanie opozycji i ludzi o oddmiennych polgądach politycznych.

Ostatnim etapem supremacji doktryny kokutai stał się okres od połowy lat 30. aż do zakończenia II wojny światowej na Pacyfiku. W tym okresie kontrolę nad większością najważniejszych stanowisk w państwie stopniowo przejęła armia, która w promowaniu ,istoty narodowej” dostrzegła szansę na prowadzenie polityki ekspansji i ustanowienie japońskiej hegemonii w Azji Wschodniej. Jednocześnie w parlamencie zwyciężyła opcja nacjonalistyczna popierająca zbrojenia i zwalczanie zwolenników demokracji, w tym wybitnych konstytucjonalistów i ekonomistów. Przełomem w rozumieniu doktryny kokutai stał się rok 1937, w którym uchwalono ministerialną interpretację tego terminu pod nazwą Kokutai no hongi jako najważniejszego obowiązku moralnego Japończyków wobec cesarza i państwa. Oprócz odniesień do tradycyjnego boskiego pochodzenia władcy, a także obowiązku lojalności wobec niego, dokument przekazywał konieczność wspierania armijnej polityki agresji wobec sąsiadów oraz wspomniał o szczególnej misji Japończyków, jaką miała być hegemonia w Azji Wschodniej. Kokutai no hongi, choć obowiązywał zaledwie osiem lat, usprawiedliwiał wszystkie popełnione przez Japonię agresje i zdrodnie wojenne. Do chwili oficjalnego zniesienia doktryny kokutai przez amerykańskie władze okupacyjne w październiku 1945 
roku, a także jej zanegowania w nowej Konstytucji Japonii z 1947 roku, można opiasać jej historyczny rozwój następująco:

1. Japonia jest krajem stworzonym przez Bogów. Japonią rządzi nieprzerwana dynastia cesarzy, którzy pochodzą z tej samej linii dynastycznej, dzięki czemu Japonia zachowała ciągłość historyczną.

2. Cesarz ma boskie pochodzenie, w konsekwencji tego jest również uważany za boga (jap. Aramikami). Cesarstwo Japonii jest boskim krajem.

3. Cesarz utożsamiany jest z suwerennością całego narodu, z którym tworzy jedną wielką rodzinę (jap. kazoku kokka). Relacje pomiędzy władcą a ludem przypominają relacje pomiędzy dobrym ojcem a jego oddanymi dziećmi.

4. Lud japoński jest homogeniczny, tj. jednolity pod kątem rasy, języka, kultury, poglądów i aspiracji, a zatem tworzy jedno ciało, które funkcjonuje w sposób harmoniczny.

5. Harmonia nie jest stanem wiecznym, toteż aby ją utrzymać, naród ma obowiązek lojalności i synowskiej miłości do cesarza.

6. Obowiązek lojalności narodu wobec cesarza oznacza również lojalność wobec rządu, który realizuje wolę cesarza.

7. Wpieranie rządu realizującego wolę cesarza polega na zwalczaniu szkodliwych dla państwa ideologii: komunistycznej, socjalistycznej i anarchistycznej. Każda ideologia zagrażająca kokutai jest szkodliwa i należy ją zniszczyć.

8. Japończycy są wyjątkowym narodem o wyjątkowej dyscyplinie i kulturze. Służą wiernie boskiemu cesarzowi, który poprzez rząd i armię realizuje politykę korzystną dla państwa. Popieranie armii i jej decyzji oznacza popieranie cesarza.

9. Armia prowadzi politykę, której celem jest zaprowadzenie ładu i pokoju na całym świecie. Japończycy mają obowiązek uczestniczenia w tej misji jako boski naród. Pełnią w związku z tym rolę narodu wybranego. Wojna jest wyrazem boskiego planu.

Kokutai no hongi, będące dokumentem o randze państwowej, stanowiło rozwinięcie ideologii kokutai od jej wczesnej fazy (punkt 1) aż do ówczesnych realiów politycznych (punkt 9). Wykorzystując pierwotne mity założycielskie, japoński rząd całkowicie usprawiedliwiał przed narodem fakt trzech agresji (kolejno w latach 1931, 1937 i 1941) oraz popełniania zbrodni wojennych. Nawet w obliczu totalnej klęski w II wojnie światowej dla rządu ważniejsze od uratowania życia Japończyków i ocalenia kraju przed kolejnymi zniszczeniami miało okazać się negocjowanie kapitulacji z warunkiem zachowania „charakteru narodowego" jako przesłanki istnienia państwa i narodu japońskiego. Brak zgody Amerykanów i bezwarunkowa kapitulacja nie oznaczały jednak końca istnienia Japonii. Dzięki reformom w latach 40. i 50. kraj ten stał się potęgą gospodarczą i jednym z przykładów dobrze prosperującego narodu. Doktryna kokutai w swojej radykalnej postaci doprowadziła Japonię do upadku, z którego podnieśli ją politycy prześladowani w latach 30 . za swoje niewłaściwe poglądy. 


\section{Bibliografia}

\section{Teksty źródłowe i akty prawne}

S. Aizawa, 新論 (Shinron — pol. Nowe Tezy), http://www.1-em.net/sampo/sinron/sinron/index.htm. 治安維持法，大正14年法律第46号 (Chian'ijihō, Taishō 14-nen Hōritsu Dai 46-go — pl. Prawo Ochrony Porządku Publicznego, Akt Prawny Nr 4614 roku ery Taishō), https://www.digital.archives. go.jp/DAS/meta/listPhoto?LANG=default\&BID=F0000000000000006687\&ID=M0000000000001 $757587 \&$ TYPE $=\& N O=$.

治安維持法中改正ノ件, 昭和3年勅令第129号 (Chian'ijihō chūkaisei no ken - pol. Przepisy rewidujące Prawo Ochrony Porządku Publicznego, Edykt Cesarski Nr 1293 roku ery Shōwa), https://www.digital.archives.go.jp/das/image/M2008121117141425801.

Conference on the Limitation of Armament, Washington, November 12 1921-February 61922 , http://www.ibiblio.org/pha/pre-war/1922/nav_lim.html.

大日本帝国憲法 (Dai Nippon Teikoku Kempō- pol. Konstytucja Cesarstwa Japonii), http://www. ndl.go.jp/constitution/etc/j02.html.

Y. Fukuzawa, 文明論之概略 (Bunmeiron no Gairyaku — pol. Zarys Teorii Cywilizacji), Tōkyō 1875, http://www.geocities.jp/hgonzaemon/bunmeironnogairyaku.html.

Y. Fukuzawa, 尊皇論 (Sonnō Ron - pol. Dyskusja nad Wiernością Wobec Cesarza), [w:] Y. Fukuzawa, Nihon Teishitsu Ron, Tōkyō 1887.

1890年 (明治23年) 10月31日付官報 (1890-nen, Meiji 23-nen, 10-gatsu, 31-nichigetsu Kampōpl. „Gazeta Kampō” z 31 października 1890 r.), http://dl.ndl.go.jp/info:ndljp/pid/2945456/3.

穀梁傳 (Gǔliáng Zhuàn - pol. Komentarze Gulianga).

汉书：卷10成帝紀 (Hànshū: Juăn 10 Chéngdì Ji - pol. Księga Hanów, t. 10, Roczniki Cesarza Chengi).

K. Katō, 国体新論 (Kokutai Shinron - pol. Nowa Teoria Kokutai), Tōkyō 1874, http://dl.ndl.go.jp/ info:ndljp/pid/759337.

H. Katō, 立憲政體略 (Rikken Seitai Ryaku - pol. Zarys Władzy Konstytycyjnej), Tōkyō 1868.

国体明徵二関スル政府声明経過，1935年8月3日 (Kokutai Meichō ni kansuru Seimei Keika 03.08.1935 - pol. Wprowadzenie deklaracji w sprawie interpretacji kokutai z dnia 3 sierpnia 1935 roku), http://www.archives.go.jp/ayumi/kobetsu/s10_1935_02.html.

国体明徵二関スル再声明7通牒ス，1935年10月15日 (Kokutai Meichō ni kansuru Saiseimei o Tsūchōsu 15.10.1935 — pol. Ponowna notyfikacja w sprawie interpretacji kokutai z dnia 15 października 1935 roku), https://www.jacar.archives.go.jp/aj/meta/MetSearch.cgi.

教育二関スル勅語 (Kyōiku ni kansuru Chokugo — pl. Cesarski Reskrypt o Edukacji), http://www. archives.go.jp/ayumi/kobetsu/m23 1890 02.html.

T. Minobe,「一身上の弁明」演説: 現代語訳 (,ISshinjō no benmei” enzetsu: gendai goyaku — pol. Przemowa pt. „,moje wyjaśnienie”: współczesne tlumaczenie), dokument elektroniczny.

國體の本義 (Kokutai no hongi - pol. Podstawowe znaczenie charakteru narodowego), ed. Mombushō, Tōkyō 1937.

N. Motoori, 直毘霊 (Naobi no Mitama - pol. Ścieżka Bogów), przedruk pracy wydany w Tokio w 1914 r.

S. Yamanaga, 中朝事実 (Chūchō Jijitsu — pol. Obecne fakty o wtadzy centralnej), Tōkyō 2015.

\section{Opracowania}

日本教科書近代編 (Nihon Kyōkasho Kindaihen - pol. Japońskie podręczniki, wersja współczesna), t. 18-19, red. T. Kaigo, Tōkyō 1963.

Studia nad Autorytaryzmem i Totalitaryzmem 40, nr 2, 2018

(C) for this edition by CNS 
文化評論, 1976年臨時増刊号 (Bunka Hyōron, 1976-nen rinjizōkan gō - pol. „Krytyka Kulturalna”, nr specjalny z 1976 roku).

明六雑誌 (Meiroku Zasshi), Dai 1-43 Go, Tōkyō 1874-1875.

Antoni K., Shintō und die Konzeption des Japanischen Nationalwesens (Kokutai): der religiöse Traditionalismus in Neuzeit und Moderne Japans, Boston 1998.

Arimoto S., 建国の由来と国体の本義 (Kenkoku no yurai to kokutai no hongi — pol. Źródta powstania państwa i podstawowe znaczenie charakteru narodowego), Tōkyō 1937.

Beasley W.G., Japanese Imperialism 1894-1945, Oxford 1999.

Blocker H.G., Starling C.L., Filozofia japońska, Kraków 2008.

Braisted W.R., Meiroku Zasshi: Journal of the Japanese Enlightenment, Harvard 1976.

Brownlee J.S., Four Stages of the Japanese Kokutai (National Essence), zapis przemówienia z konferencji JSAC na Uniwersytecie Brytyjskiej Kolumbii, październik 2000 roku.

Fridell W.M., National Essence; National Polity (Kokutai), [w:] Modern Japan: An Encyclopedia of History, Culture and Nationalism, red. J.L. Huffman, New York-London 1998.

Gauntlett J.O., Hall R.K., Kokutai no Hongi: Cardinal Principles of the National Entity of Japan, Cambridge 1949.

Hachirō M., 加藤弘之の前期政治思想 (Katō Hiroyuki no Zenki Seiji Shisō - pol. Niegdysiejsze Doktryny Polityczne Hiroyukiego Katō), Tōkyō 1983.

Ida T., 上杉慎吉: 天皇制国家の弁証 (Uesugi Shinkichi: tennōsei kokka no benshō-pol. Uesugi Shinkichi: dowód na państwowy system cesarski), Tōkyō 1989.

Ineaga S., The Pacific War 1931-1945, New York 1978.

Josephson J.A., The Invention of Religion in Japan, Chicago 2012.

Kita I., 国体論及び純正社会主義 (Kokutairon oyobi junsei shakaishugi — pol. Kokutai i czysty socjalizm), Kyōto 2007.

Kitagawa J.M., The Japanese kokutai (National Community) History and Myth, „History of Religions" 1976, vol. 13, no 3.

Kodansha Encyclopedia of Japan, t. 4, Tōkyō 1983.

Kołodziejski M., Takahashi Korekiyo 1854-1936 a gospodarka międzywojennej Japonii, Warszawa 2006.

Kość A., Filozoficzne podstawy prawa japońskiego w perspektywie historycznej, Lublin 2001.

Lavelle P., L'essence nationale du Japon, [w:] Y.M. Allioux, Cent ans de pensée au Japon, t. 2, Arles 1998.

Lisiecki M., Kokutai-no hongi w japońskim dyskursie nacjonalistycznym, Torun 2010.

López J.V., Beyond words: the kokutai and its background, „Història Moderna i Contemporània” 2006, $\mathrm{nr} 4$.

McClain J.L., Japan: A Modern History, New York 2002.

Macé F., Deux interprétations croisées du shintō, le père Martin et Katō Genchi, [w:] FranceJapon: regards croisés, red. C. Mayaux, Bern 2007.

Minobe, 憲法講話 (Kempō Kōwa- pol. Wyktad o Konstytucji), Tōkyō-1921.

Moroi T., Takemura M., 関東地震（1923年9月1日）による被害要因別死者数の推定 (Kanto Jishin - 01.09.1923 in yoru higai yōin betsu shisha kazu no suite — pol. Szacunek liczby ofiary spowodowanych przez trzęsienie ziemi na Nizinie Kantō), „Journal of Japan Association for Earthquake Engineering" 2004, vol. 4, no 4.

Mosse G.L., Kryzys ideologii niemieckiej, Warszawa 1972.

Nagai T., 転向手記 (Tenkō shuki — pol. Memorandum zmian), Tōkyō 1935.

Nishikawa S., 国体の本義と皇道財政 (Kokutai no hongi to kōdōzaisei - pol. Podstawowe znaczenie charakteru narodowego i finanse publiczne cesarskiej drogi), Shimonseki 1935.

Noda Y., Comparative Jurisprudence in Japan: Its Past and Present, part I.

Ochiai N., Ueda K., Haga Y., Fujioka S., 明治文学全集44, (Meiji bungaku zenshū 44 - pol. Kompletna Kolekcja Literatury Meiji 44), Tokyo 1968.

Studia nad Autorytaryzmem i Totalitaryzmem 40, nr 2, 2018

(C) for this edition by $\mathrm{CNS}$ 
Okudaira Y., 治安維持法小史 (Chian'ijihō shōshi一 pol. Krótka historia Prawa Ochrony Porządku Publicznego), Tōkyō 2006.

Pałasz-Rutkowska E., Działania armii japońskiej na rzecz obrony kokutai, narodowego charakteru, pod wptywami obcymi (lata trzydzieste XX w.), „Japonica” 1993, nr 1.

Pałasz-Rutkowska E., General Masaki Jinzaburō and the Imperial Way Faction (Kōdōha) in the Japanese Army, 1932-1936, Warszawa 1990.

Piegzik M.A., Rozwój szkół prawa w Japonii w okresie ery Meiji, „Folia Iuridica Univeristatis Wratislaviensis" 2016, t. 5, nr 1.

Power J.E., The Japanese Constitution and the Militarists, „Pacific Affairs” 1942, no 15.

Rosenkranz G., Shinto - der Weg der Götter, Wachtendonk 2003.

Sakamoto Y., 佐久間象山の洋学研究とその教育的発展一幕末期における軍事科学を媒介と した洋学の普及現象(Sakuma Shōzan no yōgaku kenkyū to sono kyōikuteki hatten — bakumatsuki ni okeru gunji kagaku o baikai to shita yōgaku no fukyū genshō — pol. Sakuma Shōzan i jego badania nad naukami zachodnimi i ich edukacyjnym rozwojem - popularyzacja fenomenu nauk zachodnich jako pośrednika do nauk o wojskowości w schytkowym okresie szogunatu), 教職研究 (Kyōshoku kenkyū - pol. „Przegląd nauczycielski”) 2008, no 1, s. 1-23.

Sakatani Y., 我が國體の本義 (Waga kokutai no hongi - pol. Nasze podstawowe znaczenie charakteru narodowego), Tōkyō 1936.

Sanseidō, 新明解四字熟語辞 (Shin Meikai Yoji Jukugo Jiten — pol. Nowy Stownik Japońskich Czteroznakowych Wyrażeń Idiomatycznych), Tōkyō 2007.

Suekuni M., Takano S., Senshi Sōsho (kan 31), 海軍軍戦備<1〉昭和十六年十一まで (Kaigun Gunsembi (1): Shōwa Jürokunen Jüichigatsu Made — pol. Przygotowania marynarki wojennej do wojny do listopada 1941 roku), Tōkyō 1969.

The Nanking Atrocity, 1937-38: Complicating the Picture, red. B.T. Wakabayashi, Oxford-New York 2007.

Uesugi S., 国家新論 (Kokka shinron — pol. Nowa teoria o państwie), Tōkyō 1921.

Uesugi S., 帝国憲法 (Teikoku Kempō — pol. Konstytucja Cesarska), Tōkyō 1924.

Wakabayashi B.T., Anti-Foreignism and Western Learning in Early Modern Japan: The New Theses of 1825, Harvard 1992.

Willmott H.P., Empires in the Balance: Japanese and Allied Pacific Strategies to April 1942, Annapolis 2008.

Varley P., Japanese Culture, Honolulu 2000.

Yamada S., 大日本国体概論 (Dai Nippon Kokutai Gairon - pol. Wprowadzenie do Japońskiego Kokutai), Tōkyō 1910.

Yamada Y., 国体の本義 (Kokutai no hongi - pol. Podstawowe znaczenie charakteru narodowego), Tōkyō 1933.

Yamada Y., 国体の本義に就て (Kokutai no hongi ni tsuite — pol. Odnośnie do podstawowego znaczenia charakteru narodowego), Sendai 1934.

Yamazaki M., 憲法と國體の本義 (Kempō to kokutai no hongi — pol. Konstytucja i podstawowe znaczenie charakteru narodowego), Tōkyō 1936.

Yatsuki K., 天皇と日本の近代 下「教育勅語」の思想 (Ten'nō to Nihon no kindai shi “Kyōiku Chokugo" no shisō — pol. Cesarz i współczesna Japonia — ideologia Rekrytpu o Edukacji), Tōkyō 2001.

Yeounsuk L., The Ideology of Kokugo: Nationalizing Language in Modern Japan, Honolulu 2010. 
THE ROOTS OF JAPANESE NATIONALISM AND MILITARISM - THE KOKUTAI

DOCTRINE IN THE POLITICAL LIFE OF THE EMPIRE OF JAPAN IN 1867-1945

\section{Summary}

The main goal of this article is to present the historical development of the kokutai doctrine (pol. national policy), which emerged in the Empire of Japan in 1867-1945 and which was one of the ideological foundations of the Japanese internal and foreign policy. Its formulation and subsequent consolidation in the form of legal regulations is closely related to the period of modernization and rivalry with the European colonial powers and the United States for influence on the political map of East Asia. The kokutai doctrine embodies concepts such as chauvinism, nationalism, racism, militarism, expansionism and statism. Attempts to put them into practice led to the outbreak of the World War Two in the Pacific and the total defeat of Japan against the Allies.

Keywords: History of Japan, Kokutai, Japanese imperialism, Japanese nationalism. 